\title{
SARS-CoV-2 Infection in Pregnant Women: Neuroimmune-Endocrine Changes at the Maternal-Fetal Interface
}

\author{
Marcelo Gomes Granjaa, b Amanda Candida da Rocha Oliveirac \\ Camila Saggioro de Figueiredo $^{c}$ Alex Portes Gomes ${ }^{d}$ Erica Camila Ferreira ${ }^{b}$ \\ Elizabeth Giestal-de-Araujoc, e Hugo Caire de Castro-Faria-Netob, e \\ aMolecular and Cellular Biology Program, Federal University of State of Rio de Janeiro - UNIRIO, \\ Rio de Janeiro, RJ, Brazil; ' Immunopharmacology Laboratory, Oswaldo Cruz Institute, Oswaldo Cruz Foundation - \\ Fiocruz, Rio de Janeiro, RJ, Brazil; 'Neuroscience Program, Fluminense Federal University - UFF, Niterói, RJ, Brazil; \\ ${ }^{\mathrm{d}}$ Medical Science Program, Neurology and Neuroscience, Fluminense Federal University - UFF, Niterói, RJ, Brazil; \\ eNational Institute of Technology-Neuroimmunomodulation - INCT-NIM, Rio de Janeiro, RJ, Brazil
}

\section{Keywords}

Coronavirus disease $2019 \cdot$ Severe acute respiratory

syndrome-related coronavirus 2 . Pregnancy •

Neurodevelopment · Maternal-fetal interface .

Neuroimmune interactions

\begin{abstract}
Coronavirus disease 2019 (COVID-19) caused by severe acute respiratory syndrome-related coronavirus 2 (SARSCoV-2) has devastating effects on the population worldwide. Given this scenario, the extent of the impact of the disease on more vulnerable individuals, such as pregnant women, is of great concern. Although pregnancy may be a risk factor in respiratory virus infections, there are no considerable differences regarding COVID-19 severity observed between pregnant and nonpregnant women. In these circumstances, an emergent concern is the possibility of neurodevelopmental and neuropsychiatric harm for the offspring of infected mothers. Currently, there is no stronger evidence indicating
\end{abstract}

vertical transmission of SARS-CoV-2; however, the exacerbated inflammatory response observed in the disease could lead to several impairments in the offspring's brain. Furthermore, in the face of historical knowledge on possible longterm consequences for the progeny's brain after infection by viruses, we must consider that this might be another deleterious facet of COVID-19. In light of neuroimmune interactions at the maternal-fetal interface, we review here the possible harmful outcomes to the offspring brains of mothers infected by SARS-CoV-2.

(C) 2021 The Author(s)

Published by S. Karger AG, Basel

\section{Introduction}

The coronavirus family has been described in the mid1960s, affecting humans and animals. In 2002, the first case of a severe human respiratory infection (severe acute respiratory syndrome [SARS]) was reported in Foshan, China. New cases emerged from 2003 in Mainland China,
(C) 2021 The Author(s)

Published by S. Karger AG, Basel

This is an Open Access article licensed under the Creative Commons Attribution-NonCommercial-4.0 International License (CC BY-NC) (http://www.karger.com/Services/OpenAccessLicense), applicable to the online version of the article only. Usage and distribution for commercial purposes requires written permission.
Correspondence to:

Marcelo Gomes Granja, marceloggranja @ gmail.com 
spreading to Hong Kong, Vietnam, and Canada, totaling 8,096 reported cases, including 774 deaths in 27 countries [1-4].

A second event (of the disease) in humans occurred in 2012 [5]. The coronavirus strike started this time in Saudi Arabia, expanding into several countries and causing what is now known as coronavirus Middle East respiratory syndrome (MERS-CoV). Until February 2019, 2,279 confirmed cases of MERS-CoV were reported, including 806 deaths [6].

Less than 10 years after the SARS epidemic, the world watches in disbelief the third strike of coronavirus causing a highly contagious viral pandemic pneumonia denominated coronavirus disease 2019 (COVID-19). Similar to SARS in 2002, the first cases of COVID-19 that occurred from a zoonotic transmission in China in December 2019 are linked to the wildlife and seafood trade. Spreading rapidly within China and quickly to other countries, COVID-19 reached 195 countries and infected $>100,200,107$ people, causing $>2,158,761$ deaths by January 28, $2021[7,8]$.

The novel coronavirus denominated SARS-related coronavirus 2 (SARS-CoV-2), now officially known as the cause of COVID-19, carries RNA genomic sequences similar to other coronaviruses, mainly related to SARS-CoV RNA [9]. However, the clinical symptoms related to both viruses are quite distinct. In the context of a severe case of COVID-19, a picture of multiple organ dysfunctions (MODS) has also been observed, and some authors would even suggest the change in typification from SARS to MODS [10]. Furthermore, mechanisms leading to MODS in COVID-19 seem to be related not only to the viral load that accumulates in several organs but also to the exacerbated inflammatory response ("cytokine storm") triggered by SARS-CoV-2 infection [10]. Although there are many issues to be properly addressed, knowledge of the mechanisms of infection, the clinical course of the disease, inflammatory markers, prognosis, disease complications, and mechanical ventilation strategy is rapidly growing $[11,12]$.

The broad extent of COVID-19 harm generated a major concern about more vulnerable populations. Currently, there is great interest in pregnant women COVID-19 infection and the possible impairments on the health of their babies. Although studies on COVID-19 have rapidly advanced, the effects of SARS-CoV-2 on fetal development remain unclear. Little is known about vertical transmission in COVID-19. Despite evidence indicating placental and fetal infection [13], this subject is under great discussion in the scientific community and is still controversial.
Pregnant women are especially susceptible to pathogens. The maternal-fetal interface barrier offers protection to the fetus, and when it fails, pathogens breach the innate maternal immune system and placental trophoblastic host defenses to infect the fetus by mechanisms not completely elucidated. Based on knowledge of other viruses, such as herpesviruses (varicella), Rubivirus (rubella), flaviviruses (hepatitis C, dengue, Zika virus [ZIKV]), hepadnavirus (hepatitis B), lentivirus (HIV), and parvoviruses, it is known that they are capable of circumventing placental defenses to cause detrimental and sometimes lethal effects on the fetus [14]. These effects include target organ damage (microcephaly, intracerebral calcifications, hepatosplenomegaly, chorioretinitis, microphthalmia, and deafness), fetal compromise (miscarriage, growth restriction, hemolytic anemia, and hydrops), and death [14]. All these information about other viruses rises in us a flag on the extent of SARS-CoV-2 damage to fetal development. In the case of the SARS epidemic in 2002/2003, for instance, several reports showed that clinical outcomes were worse in pregnant women than in nonpregnant women; there was an increase in abortion rates and premature births associated with SARS-CoV infection [15].

Recent studies have described that infected pregnant women have inflammatory, thrombotic, and vascular changes, suggesting that the inflammatory nature of SARS-CoV-2 infection during pregnancy can cause adverse obstetric and neonatal events [13]. Independently of a possible vertical transmission, the exacerbated maternal immune response could trigger serious consequences for fetal development, mainly on neurodevelopment. This pandemic scenario is too recent for proper longterm evaluation of its consequences in this special population. However, in the face of historical evidence of viruses causing acute and long-term consequences to mother and progeny, we must consider the outstanding possibility that this might also be another deleterious facet of COVID-19. In this context, we discussed possible harmful neurodevelopmental and neuropsychiatric outcomes in the offspring of mothers infected by SARS$\mathrm{CoV}-2$ in light of neuroimmune interactions at the maternal-fetal interface.

\section{Neuroimmunological Aspects of SARS-CoV-2 Infection}

In patients with COVID-19, the general clinical manifestations observed are respiratory failure, lymphopenia, monocyte and macrophage infiltration in lung lesions, 
hypercoagulability, thrombosis, and multiple organ failure (in severe cases). Moreover, all symptoms are accompanied by an inflammatory cascade, making evident a viral infection-related inflammation and its characteristic "cytokine storm," which, in severe cases, plays a crucial role in the clinical manifestations $[16,17]$. The uncontrolled inflammation that seems to affect the lungs could also affect other systems, including the nervous system $[10,18]$. Accordingly, clinical studies revealed that the brainstem respiratory center is the main target of SARSCoV-2 in the central nervous system (CNS), leading to dysfunction and consequent acute respiratory distress in individuals with COVID-19 [19]. The "cytokine storm" observed mainly in individuals with severe COVID-19 is marked by the uncontrolled production and release of inflammatory cytokines and chemokines (e.g., interleukins [IL-1 $\beta$, IL-2, IL-4, IL-6, IL-8, IL-10, IL-12, IL-18, IL-33], tumor necrosis factor alpha, interferons [IFN- $\alpha$, IFN- $\gamma$ ], granulocyte and macrophage colony-stimulating factor [CSF], macrophage inflammatory protein 1 alpha, platelet-derived growth factor, monocyte chemoattractant protein 1]) by activated macrophages, neutrophils, monocytes, lymphocytes, natural killer (NK) cells, and dendritic cells (DCs) [11, 20-26].

Systemically, after SARS-CoV-2 infection, an initial innate immune response takes place, leading to activation and differentiation of $\mathrm{T}$ cells by the adaptive immune system. This, in turn, plays an important antiviral role in an effort to balance the response of the immune system against the pathogen and the exacerbation of inflammation [27]. Accordingly, CD4 ${ }^{+} \mathrm{T}$ cells lead to the production of specific antibodies against the virus by B lymphocytes, while $\mathrm{CD}^{+} \mathrm{T}$ cells are cytotoxic and can kill virusinfected cells. In addition, pro-inflammatory cytokine and chemokine production is important for the recruitment of lymphocytes, monocytes, and neutrophils to the site of infection, causing an amplification of the inflammatory response [16].

The main mechanism described for SARS-CoV-2 entry into human host cells (including CNS cells) is a receptor-mediated mechanism. Indeed, several studies suggest that the SARS-CoV-2 spike glycoprotein binds to its cell receptor angiotensin-converting enzyme 2 (ACE2) in the host cell membrane along with transmembrane serine protease 2, which is responsible for the priming of viral S glycoprotein, facilitating its entrance into the cell and promoting moderate replication with a continuous release of virions from infected cells [28]. The ACE2 and transmembrane serine protease 2 receptors are expressed in the olfactory mucosa and neurons in humans and glial cells in mice. The expression of both receptors is increased in the murine model with age, fueling a discussion whether the elderly may be at greater risk due to the accumulation of SARS-CoV-2 in these cells $[29,30]$. In this context, CNS invasion mechanisms are not fully elucidated, although some potential routes have already been described. For instance, viremia may result in viral transcytosis through the blood-brain barrier (BBB) endothelial cells or epithelial cells in the choroid plexus surrounding the cerebral ventricles. In addition, SARSCoV-2 could enter via the olfactory nerve and other peripheral nerves, such as trigeminal fibers and/or the vagus nerve, which innervate different parts of the respiratory tract, including the larynx, trachea, and lungs [31-33].

Once in the CNS, SARS-CoV-2 could trigger a local inflammatory cascade stimulating the release of inflammatory mediators by local cells. In addition, it is important to note that the exacerbated systemic release of cytokines and chemokines may increase blood-brain barrier permeability and promote the activation of neuroinflammatory cascades, facilitating leukocyte migration to the CNS and SARS-CoV-2 invasion [34, 35]. The dysregulated cytokine release in the CNS also promotes neuronal hyperexcitability via activation of glutamate receptors and leads to an acute form of seizures, for example [36, 37]. It has been suggested that the exacerbated immune system response in COVID-19 can lead to inflammatory lesions and edema in the brain [38].

Moreover, neurological clinical signs such as loss of smell and taste [39-43], headache [20,44, 45], seizures [46], strokes [47], and meningitis/encephalitis [48] have also been reported in patients with COVID-19. There is already a growing body of evidence showing patients presenting both neurological and psychiatric (e.g., anxiety and depression) outcomes after infection [26, 49]. Furthermore, the role of neuroinflammation in several psychiatric disturbances is well established in the literature and could well be the main cause of such impairments observed in COVID-19 [26]. Nevertheless, more studies are necessary to strengthen this relationship in COVID-19.

\section{Pregnancy and SARS-CoV-2 Infection}

\section{Physiological Immune-Endocrine Changes at the Maternal-Fetal Interface}

The mother's body needs to adapt in order to support the growth and development of the hemiallogeneic fetus. The maternal-fetus interface is formed of a mucous mem- 
brane originated from differentiated endometrial cells, or decidua, at the beginning of pregnancy involving the fetus, umbilical cord, and placenta. This interface promotes tolerance and local defense against infections and pathogens [50-54]. Immune responses at the maternal-fetal interface need to support reception, establishment, and growth since the implantation of blastocyst until birth [55]. Fetal trophoblastic and maternal decidual immune cells interact at the maternal-fetal interface, allowing the embryo to develop in the uterus [56].

The postimplantation tissue is rich in immune cells such as leukocytes, macrophages, DCs, and T cells [57, 58]. For this reason, it was initially believed that the blastocyst triggers a maternal immune response destined for its rejection. The fetal placental unit expresses proteins of paternal origin, and for this reason, it was believed that for pregnancy to occur, the maternal immune system should be constantly suppressed. However, immune infiltrates are required to facilitate proper implantation, to maintain tolerance, and to promote a successful pregnancy [55].

The proportion of decidual immune cells vary according to the cell type and the trimester of pregnancy. NK cells represent approximately $70-80 \%$ of leukocytes at the maternal-fetal interface, macrophages are $20-25 \%$, DCs are $1.7 \%$, and T cells $3-10 \%[57,58]$. NK cells and macrophages are especially high in the first trimester of pregnancy and decrease in the second and third trimesters. On the other hand, $\mathrm{T}$ cells are few in the first trimester and increase in the third trimester. These changes, in proportions, are related to the functions they perform [54].

Decidual NK (dNK) cells are the most abundant leukocytes in the first trimester and play important roles in early pregnancy events. dNK cells regulate the invasion of fetal trophoblast cells in the decidua $[59,60]$ and arterial remodeling [61-63]. They accumulate around maternal uterine spiral arteries (SAs) before trophoblast invasion, favoring the remodeling of the SAs needed to support fetal growth [64]. dNK cells produce cytokines such as tumor necrosis factor alpha, IL-10, IL-1 $\beta$, IL-6, IL-8, TGF- $\beta$, IFN- $\gamma$, macrophage-CSF, and granulocyte-macrophage CSF. dNK cells also produce angiogenic growth factors such as vascular endothelial growth factor-C, placental growth factor, angiopoietin-1, and proteases such as matrix metalloproteases [65-70].

Macrophages are the second most abundant population of leukocytes in the early period of pregnancy, performing a variety of essential functions [71]. They are related to the remodeling of blood vessels $[63,72,73]$, trophoblast invasion [74-76], tolerance [76, 77], immunomodulation of maternal lymphocytes, and parturition initiation through the production of pro-inflammatory cytokines and prostaglandin E2 [76, 78-80]. Macrophages have an M1 profile during the peri-implantation period, changing to an M1/M2 profile when the trophoblasts invade the uterine stroma and fixate on the endometrium, allowing the placental-fetal blood supply to be adequate during the first trimester and the beginning of the second trimester [81]. Then, the deciduous macrophages change to a predominantly M2 polarity that will prevent rejection of the fetus and allow it to develop until delivery. This tolerance to the fetus occurs especially by the production of IL-10 [71, 77, 82, 83], prostaglandin E2 $[71,84]$, enzymatic activity of indoleamine 2,3 -dioxygenase $[71,77]$, and TGF- $\beta[71]$ by macrophages.

Although present in a much lower concentration than macrophages in decidua, DCs are also involved in maintaining tolerance to the fetus. DCs are found in the placental bed in both their mature and immature forms; however, the number of immature cells is much higher [85]. They undergo partial inactivation and decrease in size in the third trimester [86]. This immature state has the main function of maintaining immunological tolerance [87]. Immature DCs (DC-SIGN + iDC) can induce Treg cells during pregnancy, reinforcing their role in inducing tolerance against fetal antigens [88].

The functions of $\mathrm{T}$ cells during pregnancy are still not fully understood. In the first trimester, trophoblast cells produce the chemokine CKCL16 that interacts with the CXCR6 receptor of $T$ cells, attracting circulating $\mathrm{T}$ cells to decidua, forming a specific microenvironment [89]. Thus, deciduous $\mathrm{T}$ cells, in addition to regulating the placental microenvironment, recognize fetal antigens, without attacking them [54]. This recognition occurs through the interaction with antigen-presenting cells in the decidua, promoting tolerance to the fetus during pregnancy [90]. T cells that are suppressed during pregnancy increase next to labor; they infiltrate the maternal-fetal interface before and during delivery [91]. The decidual $\mathrm{T}$ cells have activation markers and mediators implicated in both term and preterm labor, indicating that these cells participate in this process [92].

In short, pregnancy is a pro-inflammatory environment during the first trimester, enabling implantation and placentation, then shifts to an anti-inflammatory stage, allowing fetal growth during the second trimester and finally shifts back to a pro-inflammatory stage that promotes labor and delivery during the third trimester [55]. From these perspectives, physiological changes and possible alterations at the maternal-fetal interface concerning SARS-CoV-2 infection will be further discussed. 
The Neuroimmune Changes Caused by SARS-CoV-2 in Pregnant Women

Immune mediators such as cytokines, chemokines, and neurotrophins actively participate in the development of the CNS by regulating neuronal and glial cell migration, differentiation, survival, synaptogenesis, synaptic maturation, plasticity, and programmed cell death [93-98]. Changes or interruptions in these pathways can not only affect neurodevelopment but also impair cognitive and intellectual abilities after birth. In addition, it has been widely demonstrated that disturbances in these pathways can increase the risk of psychiatric disorders [98-100].

In early periods of development, microglia are the main source of cytokines in the CNS. Microglial cells are macrophage-like cells responsible for the innate immune response in the CNS [101-103]. They respond to pathogens, infections, or cell damage [104]. Of hematopoietic origin, they colonize neural structures at embryonic ages in the late first trimester in humans [105-108]. Microglia enter the parenchyma via the bloodstream and migrate throughout the CNS, becoming self-renewing [103, 108110]. Thus, the activation of microglia can alter the profile of immune mediators produced in the CNS and therefore impact neurodevelopment $[93,94,108]$.

The particularities of pregnancy make pregnant women a risk group for infections such as those caused by viruses [111]. Notably, interference in the inflammatory state can have consequences for the mother and the developing fetus [55]. Hormone levels and the immune response show variations during pregnancy; for example, early pregnancy seems to be more susceptible to adaptive changes in response to fetal antigens, but the mother's endocrine and immune response tends to become more balanced and stable in the final stages of pregnancy. The crucial period of fetal organ development is early pregnancy, and the immune system is off balance at this stage. For this reason, fetal organ development is particularly sensitive to infections in this period [112].

The current COVID-19 pandemic is still recent, and cases of COVID-19 during pregnancy have been reported. Despite the small amount of information available, it is already clear that infection by SARS-CoV-2 induced a relevant disturbance in the immune response of pregnant women.

Viruses and bacteria can use toll-like receptors and NOD-like receptors expressed by immune cells. Maternal infections, such as sepsis, can cause damage to the fetus CNS by mechanisms that involve the activation of microglia. To fight a current infection, the pregnant woman immunological mechanisms increase the secretion of pro-inflammatory cytokines capable of crossing the placental barrier. These cytokines induce activation of the fetal microglia, dysregulating the production of cytokines in the fetus. In fact, inflammatory cytokines such as IL-6, IL-17, and IL- $1 \beta$ are elevated in CNS after birth in animals exposed to prenatal infection. This mechanism could be linked to psychiatric disorders in the offspring [113].

Severe COVID-19 patients show signs of viral sepsis. Neutrophils and neutrophil-derived extracellular traps (NETs) are critical for sepsis pathogenesis [114-116]. Veras et al. [117] demonstrated that patients with severe COVID-19 have increased levels of NETs in the plasma and tracheal aspirate. NETs were equally found in the lung tissue from autopsies of COVID-19 victims. SARSCoV-2 also induces the in vitro release of NETs by activating arginine deiminase 4 (PAD-4) in healthy neutrophils. In this way, the number of circulating neutrophils could be used as a marker of severity for patients with COVID-19 [117, 118]. It is conceivable that a similar mechanism could be operating in pregnant women with COVID- 19.

Fever and cough were the most common symptoms reported in the literature [119-126], but lymphopenia and increased levels of C-reactive protein were also frequent $[119-123,125,127-131]$. Other laboratory findings showed increased concentrations of alanine aminotransferase and aspartate aminotransferase (AST) [120], increased neutrophil count, and no differences in IL-6 levels [128]. Most pregnant women infected with SARSCoV-2 developed mild to moderate COVID-19 pneumonia $[120-122,128,130]$. Severe pneumonia occurs rarely and is related to neonatal death [119].

Abortions can be caused by different mechanisms; among them, infections are the most reported [132]. SARS-CoV-2 infection is related to acute inflammation of the placenta. Baud et al. [133] described a case of an obese 28-year-old pregnant woman in Switzerland. The patient had high fever $\left(102.5^{\circ} \mathrm{F}\left[39.2^{\circ} \mathrm{C}\right]\right)$, myalgia, fatigue, mild pain when swallowing, diarrhea, and dry cough but no pneumonia. The stillborn infant tested negative for SARS-CoV-2, and fetal autopsy showed no malformations. However, the placenta was positive for SARSCoV-2. Placental histology showed infiltrates of neutrophilsandmonocytes, in addition to funisitis (inflammation of the umbilical cord connective tissue, which indicates an inflammatory response in the fetus) [133]. Another reported case was that of a previously healthy 35 -year-old woman also presenting fever and classical symptoms of 
COVID-19. SARS-CoV-2 infection was confirmed by laboratory tests. Histological examination of the placenta showed inflammatory infiltrates with macrophages and $\mathrm{T}$ lymphocytes, in addition to the presence of diffuse perivillous fibrin. SARS-CoV-2 was located in syncytiotrophoblast cells [134].

A study conducted at the Johns Hopkins Hospital (JHH) showed that pregnant women infected with SARSCoV-2 have high concentrations of IL- $1 \beta$, but not IL- 6 , in blood samples. This pattern was similar to that found on the fetal side of the placenta, especially in asymptomatic pregnant women. In addition to placental infection, pregnant women with SARS-CoV-2 infection showed reduced viral antibody response with reduced anti-S-receptor-binding domain IgG and less neutralizing antibody detectable. The transfer of maternal $n A b$ via placenta was also inhibited by SARS-CoV-2 infection. Notwithstanding this, long-term implications of placental inflammation in postnatal life need to be investigated [135]. Besides, placental histopathology has already been associated with neurodevelopmental disabilities such as autism spectrum disorders (ASDs) and attention-deficit/hyperactivity disorder (ADHD) [136, 137].

Preterm births have been reported in pregnant women infected with SARS-CoV-2 [120, 121, 130, 138, 139]. Viruses are capable of changing the trophoblast cell response to commensal bacteria from the microbiota present on the mother-fetus interface. Under normal conditions, these cells secrete IFN- $\beta$, which influences receptivity to the fetus and can prevent vertical transmission of virus [140]. Viral infections decrease the levels of IFN- $\beta$ from trophoblastic cells, changing the inflammatory profile of the mother-fetus interface. As a consequence, viruses impair fetal receptivity and increase the chance of preterm birth [141]. The onset of labor includes cytokines and chemokines secretion from immune cells that infiltrate and reside at the maternal-fetal interface [142]. Thus, the potential activation of inflammatory pathways by SARS-CoV-2 may result in preterm birth.

Several studies reported that COVID-19 symptoms can be intensified after labor. A study conducted with 8 pregnant patients, 6 laboratory-confirmed SARS-CoV-2 infections and 2 highly suspected SARS-CoV-2 infection cases, and 5 pregnant cases excluding SARS-CoV- 2 infection admitted to the Maternal and Child Health Hospital of Hubei Province, Wuhan, China. The patients with SARS-CoV-2 were all in the third trimester, and their ages ranged from 26 to 35 years. Before labor, $87.5 \%$ of the patients had no fever or cough. Three of the 7 patients developed fever and typical ground-glass opacities in the lungs at 1 or 2 days postpartum. Only 1 patient had fever and typical ground-glass opacities on prepartum admission. White blood cell counts, lymphocytes, and C-reactive protein of all patients were normal or slightly higher before labor. On the other hand, they had increased white blood cell counts and C-reactive protein levels, and lymphopenia occurred in $62.5 \%$ of the pregnant women after labor [143].

The effects of SARS-CoV-2 on pregnancy are still unclear. Studies suggest that pregnant women are generally in a risk group for infectious diseases (including COVID-19) due to immunological and hormonal changes at this period [144, 145]. In fact, patients with COVID-19 present activation of both Th1 and Th2 axis, resulting in increased levels of IFN- $\gamma$ and IL- $1 \beta$, in addition to IL-4 and IL-10 [11]. This feature can favor the immune response to SARS-CoV-2 in pregnant women, which may result in a lower severity when compared to nonpregnant individuals [120].

\section{SARS-CoV-2 Infection-Related Neuroimmune-}

\section{Endocrine Alterations over Pregnancy}

Maternal infections by viruses have been extensively reported to lead to several neuropsychiatric outcomes (e.g., psychosis, depression, anxiety, schizophrenia spectrum disorders, cognitive deficits, and sensory-motor deficits) [146]. Furthermore, abnormal levels of inflammatory mediators $[147,148]$ and steroid hormones [149] after prenatal infections can lead to disruption in fetal development. In addition, it was recently proposed that the increased levels of cytokines observed in COVID-19 may lead to dysfunctions in the negative feedback between hypothalamic-pituitary-adrenal (HPA) axis (hyperactivity or hypoactivity) and immune system, which could be behind mental health disturbances found in COVID-19 patients [26]. Since acute infections can potentially activate the HPA axis, SARS-CoV-2 infection-related hormonal changes are expected to modulate the maternal-fetal interface as well as producing long-term neuronal effects.

In light of a neuroendocrine-immune concept, the placenta is far more than an organ for protection and nutrition connecting mother and fetus [150,151]. The mother's placenta displays a substantial complexity acting as a neuroendocrine organ, capable of secreting neuroactive signaling factors (e.g., oxytocin, melatonin, serotonin, and thyrotropin-releasing hormone), steroid hormones (e.g., progesterone, estrogens, and glucocorticoids), growth hormones, and others. These signaling factors can act through autocrine, paracrine, and endocrine path-
Neuroimmunomodulation 2021;28:1-21 DOI: $10.1159 / 000515556$
Granja et al. 
ways, which could reach the maternal and fetal circulation, promoting fundamental regulatory functions [150, 151]. During pregnancy, neuroendocrine-immune interactions become even more complex. The maternal, fetal, and placental HPA axes (an important regulatory mechanism of excessive production of inflammatory mediators through the release of glucocorticoids [e.g., cortisol]) work in an integrated manner to avoid any adverse effects of stressors on both mother and offspring [151].

In the course of pregnancy, the levels of maternal glucocorticoids and progesterone increase and are essential for pregnancy maintenance, as low levels of progesterone have been associated with preterm labor [152] and spontaneous miscarriage [153]. It is noteworthy that progesterone can also shift the cytokine balance of immune responses toward an anti-inflammatory profile and may induce the expansion of regulatory $\mathrm{T}$ cells $\left(\mathrm{CD} 4^{+}\right.$and $\left.\mathrm{CD} 8^{+}\right)$ at the maternal-fetal interface $[154,155]$. There is evidence that $\mathrm{H} 1 \mathrm{~N} 1$ influenza virus infection in pregnant mice disrupts the production of progesterone and placental architecture (increased regions of fetal endothelial cell death, degradation of the spongiotrophoblast layer, and fibrinoid necrosis in the maternal decidual layer) and dysregulates inflammatory responses, promoting preterm labor, impairment of fetal growth, and increased fetal mortality [156]. In this context, it seems reasonable to presume that SARS-CoV-2 infection in pregnant women may also lead to disruptions of progesterone production, which in turn could generate major complications for fetal development and health.

As progesterone, balanced levels of glucocorticoids during pregnancy are essential for suitable fetal brain development. As cited above, the infection by SARS-CoV-2 has been proposed to unbalance HPA axis activity [26], which raises concern about the pregnant women population. To protect the fetus from excessive exposure to these hormones throughout gestation, a mechanism such as the fetoplacental expression of the glucocorticoid-inactivating enzyme $11 \beta$-hydroxysteroid dehydrogenase type 2 (an enzyme that metabolizes bioactive cortisol into bioinactive cortisone) is elicited [149]. Under some circumstances, as high fetus exposure to glucocorticoids evoked by stressors (e.g., maternal infections and/or excessive exposure to inflammatory mediators), this regulatory mechanism can be disrupted; potentially triggering a mechanism termed fetal or developmental "programming" $[149,157,158]$. Early life programming increases the fetus susceptibility to diseases including neuroendocrine and psychiatric disorders in adulthood [159] and influences adult behavior and HPA axis responses [157].

Maternal-Fetal SARS-CoV-2

Transmission: Effects on the Fetus
In this respect, we can propose, and it will not be surprising, that SARS-CoV-2 may damage fetal brain development and lead to neuropsychiatric disturbances in childhood or adulthood by fetal "programming" triggered by excessive exposure to maternal glucocorticoids.

Of note, since cross talk between inflammatory mediators and steroid hormones in the placenta is crucial for proper fetal brain development [160], we hypothesize that the exacerbated inflammatory response triggered by SARS-CoV-2 infection could also disrupt such interactions and impair the offspring's neurodevelopment. Correspondingly, maternal inflammation is thought to result in elevated pro-inflammatory cytokines that can cross the placental barrier and access placental cells via maternal blood in the SAs and intervillous spaces, influencing the fetal brain development [160]. Studies have shown that maternal immune activation (MIA) induced sustained alterations in motility patterns of fetal microglia, which may contribute to subsequent risks for cognitive diseases [161]. Moreover, it has been demonstrated that MIA may lead to an increase in Th17 cells in maternal serum, which can be associated with ASD-related cortical and behavioral abnormalities in the offspring [113]. Notwithstanding this, MIA can lead to a disruption in immune tolerance, blood circulation, and cytoarchitecture of the placenta [160] and may alter the expression of genes that encode important fetal endocrine and growth factors, which are associated with schizophrenia and ASD [162].

Overall, although it can be possible all remodeling at the maternal-fetal interface (immune and hormonal changes) during pregnancy may be slightly protecting the offspring brain development against severe COVID-19 outcomes $[163,164]$, there is a large body of evidence, as discussed here, that support various conceivable ways by which SARS-CoV-2 infection could impair these protective maternal mechanisms (Fig. 1). However, further studies are needed to better understand how such mechanisms could be impaired by the SARS-CoV-2 infection.

\section{Neuroimmune Disorders Associated with Maternal Infections}

Immune and endocrine activation during pregnancy, as well as infections and stress, may influence fetal neurodevelopment and increase the risk of neurological and psychiatric diseases during postnatal life [165-176]. Stress conditions, such as anxiety and depression, are associated with a number of psychiatric disorders, such as ASD [177-179], depressive symptoms [180], anxiety, 
Fig. 1. Hypothetical neuroimmune-endocrine mechanisms by which SARS-CoV-2 infection may lead to damages in fetal brain development. Under normal conditions, the maternal, fetal, and placental HPA axes work in an integrated manner to avoid damages to fetal neurodevelopment. During pregnancy, the levels of placental $11 \beta-H S D 2$ (glucocorticoid-inactivating enzyme) rise throughout gestation, ensuring proper fetus exposure to glucocorticoids. Steroid hormones (e.g., progesterone) also increase during gestation progress, shifting the cytokine balance toward an anti-inflammatory profile at the maternal-fetal interface. During a viral infection (e.g., SARS-CoV-2 infection), such regulatory mechanisms could be impaired. In these circumstances, SARSCoV-2 (1) may lead to a disruption in the suitable regulation of the HPA axis; (2) glucocorticoids controlling mechanisms, as placental $11 \beta-H S D 2$ expression, may be disrupted and rise fetal exposure to these hormones, which could lead to neuropsychiatric disturbances in childhood or adulthood; (3) a dysregulation of progesterone production by the placenta can contribute to an unbalanced inflammatory environment for the fetus; and (4) the exacerbated maternal inflammation may break proper immune-endocrine interactions and impair the offspring's neurodevelopment (e.g., ASD-related cortical and behavioral abnormalities). SARS-CoV-2, severe acute respiratory syndrome-related coronavirus 2; HPA, hypothalamic-pituitary-adrenal; $\mathrm{CRH}$, corticotrophin-releasing hormone; $11 \beta$-HSD2, $11 \beta$-hydroxysteroid dehydrogenase type 2 ; ASD, autism spectrum disorders.

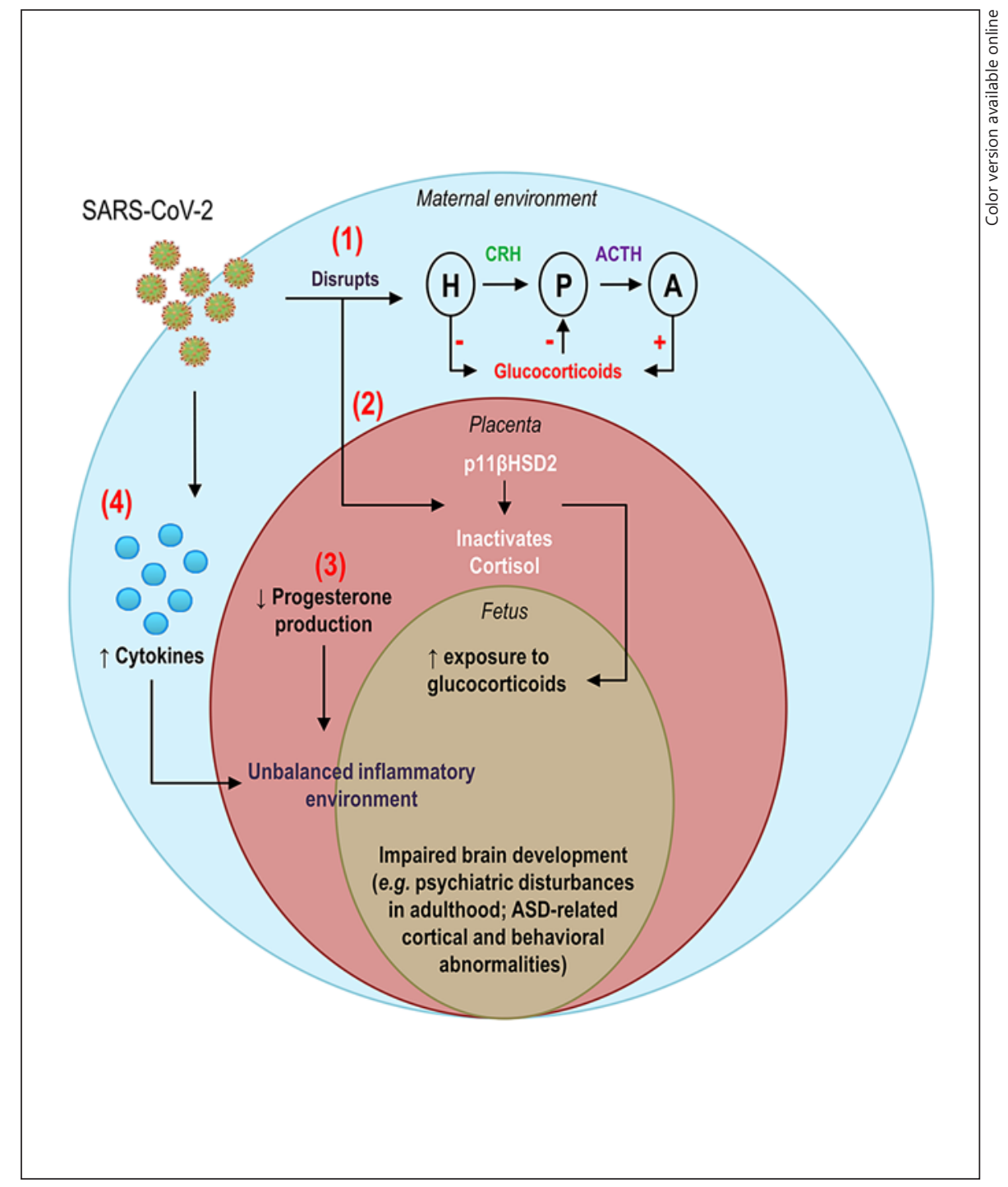

borderline personality disorder, eating disorders [181], ADHD [179, 182-184], and schizophrenia [185], which arise later in life.

SARS-CoV-2 infection is very recent; it is not yet possible to assess whether and what neurological consequences may occur in children born from mothers who had COVID-19. However, based on its clinical manifestations and making a parallel with other infections already described in the literature, attention is drawn to the risks represented by COVID-19 from a neurological point of view.

Fever was one of the most reported symptoms among both pregnant and nonpregnant patients infected with SARS-CoV-2. Fever during pregnancy can have different outcomes, depending on the cause (pneumonia, virus, bacterial infections, malaria, genitourinary tract infections, etc.), temperature elevation, its duration, and the gestational period $[186,187]$. Elevated body temperature of the pregnant woman can lead to events that compromise the development of the fetus such as vascular disruptions and placental infarction [187, 188]. Maternal fever during pregnancy has been associated with problems in fetal development as neural tube defects, congenital heart defects, oral clefts, growth retardation, abortions, and fetal death $[186,187,189,190]$. The CNS is one of the most affected, leading to behavioral and cognitive problems that can develop during postnatal life [187] as an increased risk for development of ADHD [191] and autism [192-194].

Lymphopenia is frequently observed in COVID-19 patients. In fact, the lymphocyte count, as well as the neu- 


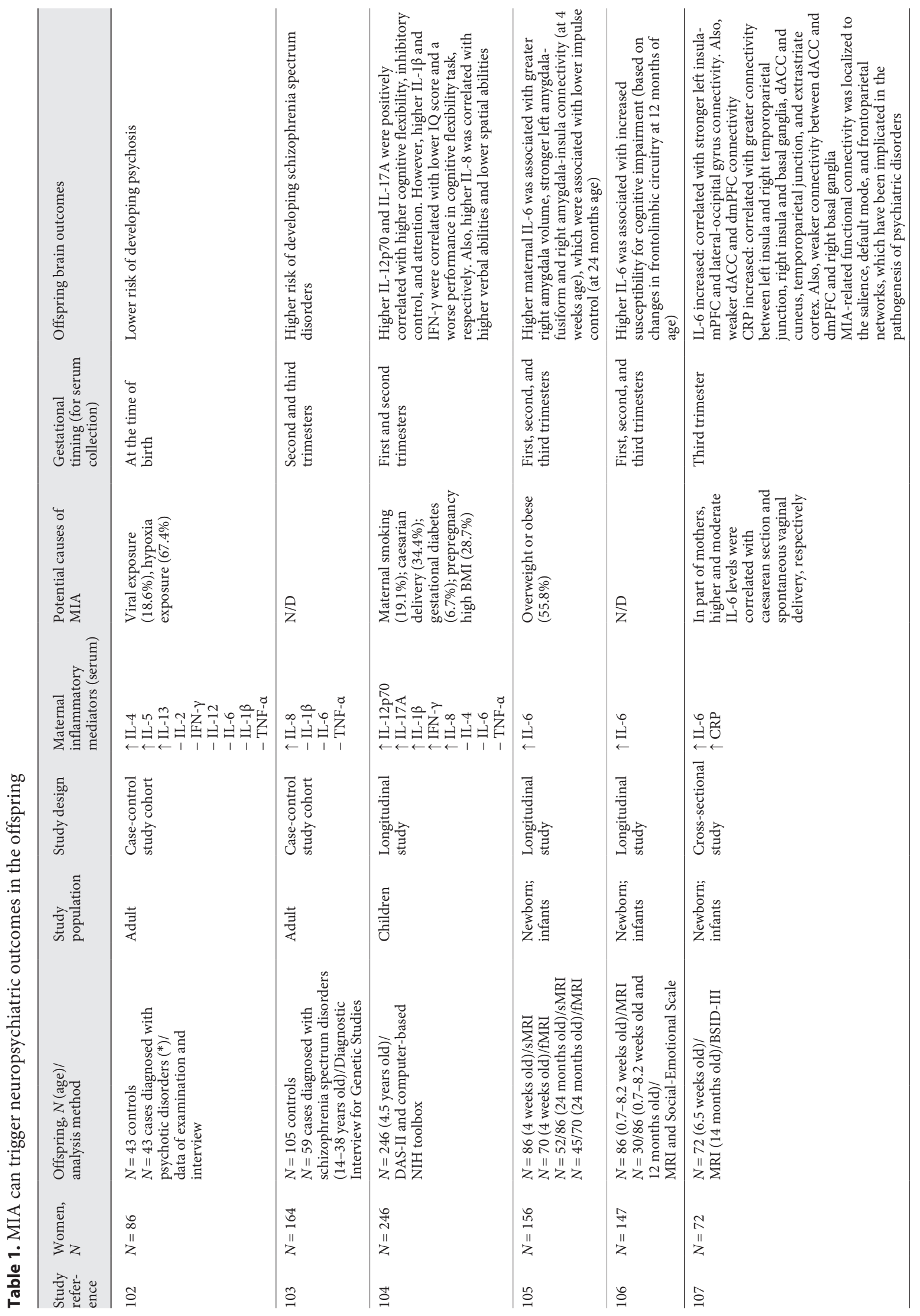




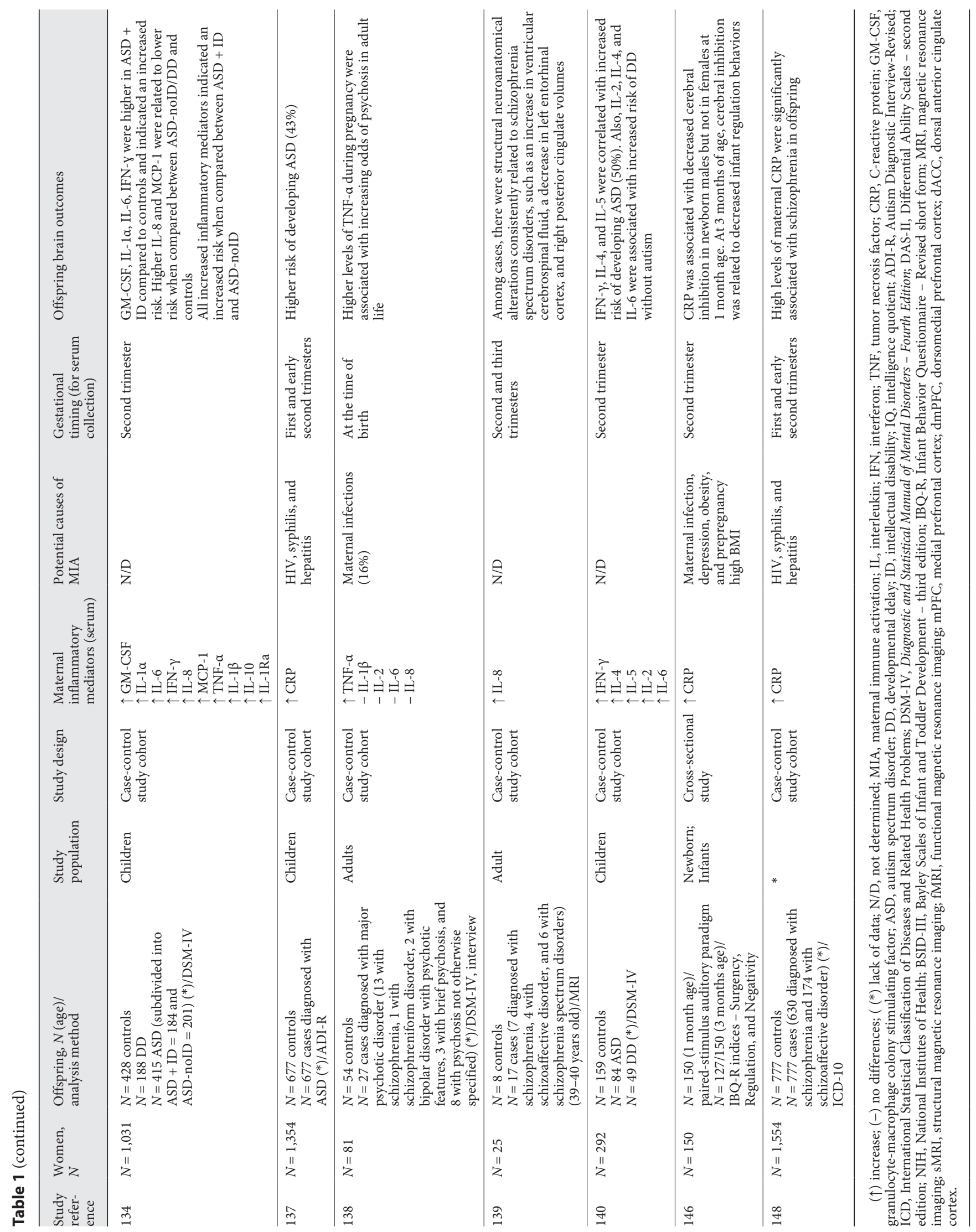


trophil count, has been associated with the severity of COVID-19 [118, 195, 196]. Some hypotheses have been raised to explain lymphopenia. (1) The death of lymphocytes could be a result of direct infection by SARS-CoV-2. (2) The drop in the number of lymphocytes could be a result of the damage caused by SARS-CoV-2 to organs such as the thymus and spleen. (3) The death of lymphocytes could be caused by the cytokine storm characteristic of some viral infections [197]. The latter has been widely reported in the literature [198-202] and can influence the fetal development in many ways as well as induce clinical manifestations that will only appear in postnatal life [55]. Neuropsychiatric and neurodevelopmental disturbances can be associated with MIA and have been widely reported in the literature, such as schizophrenia spectrum disorders, ASD, and ADHD (Table 1) [113, 173-175, 203209].

Pregnant women with COVID-19 have elevated levels of CRP. CRP is used as a biomarker of systemic inflammation, even during pregnancy $[210,211]$. Elevated CRP levels in the mid-term of pregnancy are correlated with late gestational complications [212], increased risk for preeclampsia [213], and increased risk of neonatal sepsis [214]. In addition to complications related to pregnancy itself, high levels of CRP can influence brain development [215] and are also related to psychiatric disorders such as schizophrenia [216, 217], autism [206], and bipolar disorder [218].

Another aspect that must be considered is the psychological stress caused by the COVID-19 pandemic in pregnant women. In addition to being more susceptible to infections, pregnant women during the pandemic have been commonly deprived of regular prenatal consultations. Social isolation, fear, insecurity, and lack of prenatal care contribute to maternal mortality and can interfere with fetal development [219]. An example of this is the increased risk of developing preeclampsia in women who experience depression or anxiety during pregnancy [220222]. Vasoactive substances, hormones, and other neuroendocrine mediators have their excretion altered during depression, contributing to the increase in blood pressure, which, in turn, increases the risk of preeclampsia $[221,223]$.

The literature has shown that SARS-CoV-2 has a correlation with hypertensive complications, such as preeclampsia [119, 126, 224-229]. Hosier et al. [126] demonstrated a case report in which a patient already had a history of gestational hypertension and had her condition aggravated after SARS-CoV-2 infection. The patient was in the second gestational trimester and, until then, had no indication of gestational hypertension. After infection, her clinical and laboratory tests showed hypertension, proteinuria, elevated transaminases, and low platelet counts, indicating a diagnosis of severe preeclampsia. The examination of the placenta showed inflammation, with inflammatory infiltrates composed of macrophages and $\mathrm{T}$ lymphocytes, in addition to the virus in the syncytiotrophoblast cells, which suggests that COVID-19 is related to placental inflammation, which may favor the appearance of preeclampsia [126]. Other evidence shows that SARS-CoV-2 promotes lesions in the placenta that increase decidual arteriopathy and maternal vascular malperfusion, findings that are compatible with hypertensive disorders and preeclampsia [230]. It is worth mentioning that preeclampsia is mostly observed in the severe forms of COVID-19 [226] and pregnant women who have a history of hypertensive disorders of pregnancy [126, 231, 232].

To date, most evidence indicate that vertical transmission of SARS-CoV-2 from mother to fetus does not occur $[120,233,234]$. Only 2 reports indicate that vertical transmission could occur $[235,236]$. However, even if there is no vertical transmission, this does not exclude dangers for fetal development. The maternal immune system, although naturally altered due to the peculiarities of pregnancy, has mechanisms to fight pathogens. Some adaptive immune responses are downregulated during pregnancy as decreased numbers of $\mathrm{T}$ and $\mathrm{B}$ cells. On the other hand, NK cells and monocytes respond strongly to viral challenges, producing inflammatory mediators [237]. Thus, even if the virus is not able to cross the placenta and reach the fetus, several complications can occur because of the maternal inflammatory response to the virus. Cytokines and hormones of maternal origin can freely cross the placenta, a phenomenon called "vertical transfer" [99].

Thus, it can be said that the impact that the infection will have on fetal development will depend on a set of factors, such as the trimester of pregnancy and the location of the pathogen (whether they are present in the maternal-fetal interface or only in maternal tissues) in addition to the maternal-placental immune response [55]. Based on the data available in the literature, COVID-19 in pregnant women presents itself mostly in mild forms, with most fetuses born alive. Thus, since mothers are subjected to an exaggerated inflammatory response, attention is drawn to possible consequences for neurodevelopment as well as neural and psychiatric diseases that may arise in postnatal life (Fig. 2). 
Fig. 2. Major pathways for neurodevelopmental and neuropsychiatric outcomes in the offspring of mothers infected by SARSCoV-2. SARS-CoV-2 infection during pregnancy could lead to devastating outcomes in the offspring's brain, and in this case, there are 2 major pathways that can be responsible for affecting brain health and its proper development. a First, the virus could supposedly cross placental tissues (vertical transmission) and reach the fetus' brain, leading to harmful effects. b Second, despite the SARS-CoV-2 vertical transmission possibility, the virus can trigger an exacerbated inflammatory response in the infected pregnant mother (upper panel). The inflammatory mediators produced by the mother can effectively cross all placental barriers and the fetus' $\mathrm{BBB}$, which can trigger neurodevelopmental and/or neuropsychiatric damages in the offspring (e.g., neuroanatomical changes, cognitive impairments, schizophrenia spectrum disorders, ASD, and ADHD manifestations) (bottom panel). SARS-CoV-2, severe acute respiratory syndrome-related coronavirus $2 ; \mathrm{BBB}$, blood-brain barrier; ASD, autism spectrum disorders; ADHD, attention-deficit/hyperactivity disorder.

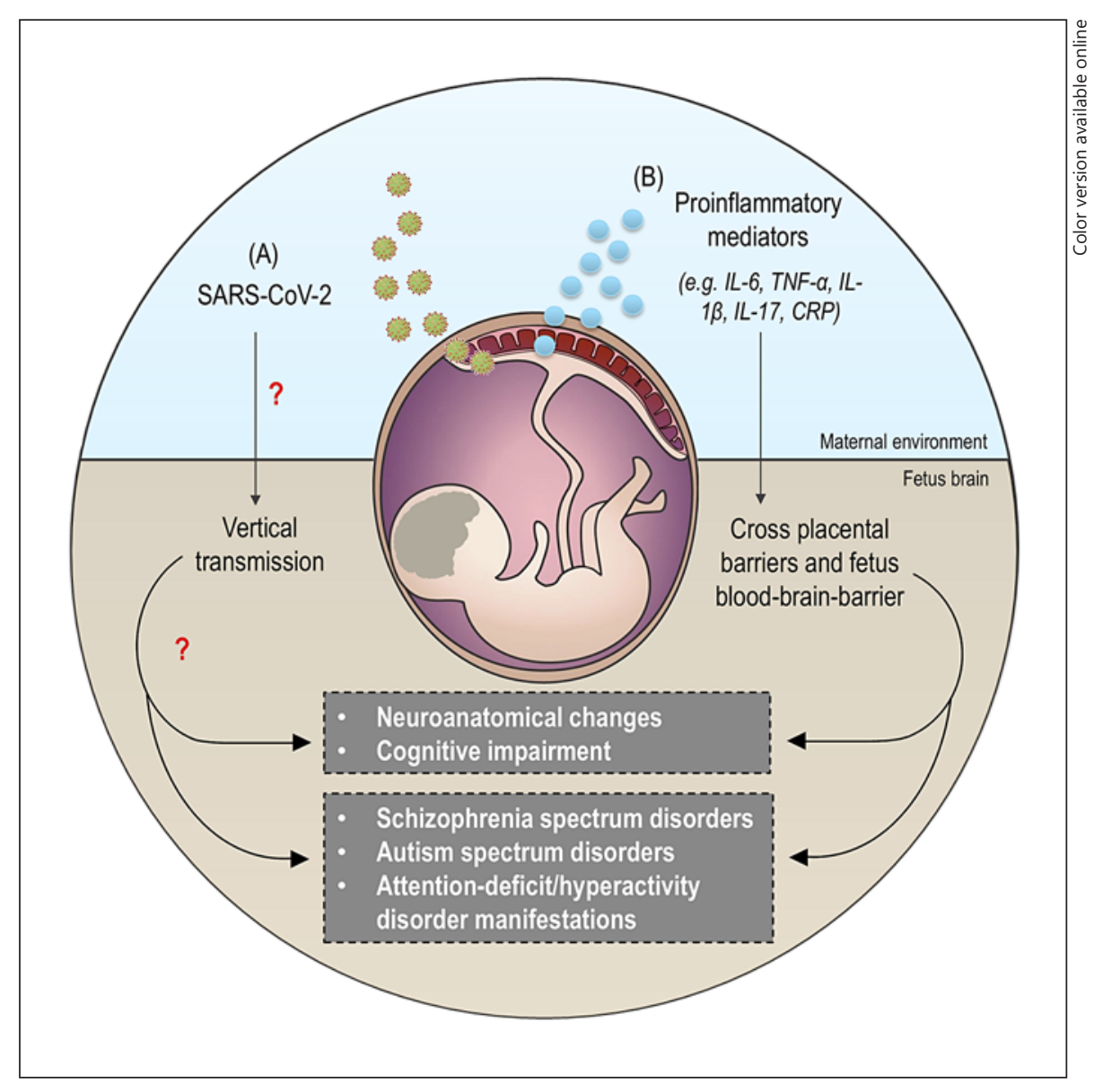

The Risk of Fetal and Neonatal SARS-CoV-2 Infection

The clinical manifestations of COVID-19 in pregnant women appear to remain the same as in nonpregnant patients. It is of great importance whether the new coronavirus can be transmitted vertically from the pregnant woman to the fetus. The youngest baby tested positive for SARS-CoV-2 was $36 \mathrm{~h}$ old [235].

In the SARS-CoV pandemic that occurred in 20022003, from 12 pregnant women infected, 3 died, 4 miscarried in the first trimester, and 4 gave birth prematurely [112]. In the MERS-CoV infection, from 11 women infected, 3 died in the second trimester of pregnancy, 6 patients required hospitalization in the intensive care unit, and only 2 neonates died [238].

Although the question of SARS-CoV-2 transplacental infection (vertical transmission) has not been conclusively answered, reports of neonatal infection with COVID 19 shortly after delivery suggest transplacental migration or horizontal transmission by direct contact with the sur- face at birth or during breastfeeding as the mode of viral migration [239]. Transplacental migration is different from the direct or "mechanical" transfer of viruses, as they can occur in prenatal procedures such as amniocentesis, premature birth, and hemorrhage [240].

Clinical evidence of transplacental viral migration requires the isolation of viral nucleic acids in fetal or placental tissues in the sterile intrauterine environment and/ or in the newborn as well as the adequate exclusion of horizontal transmission, such as direct or mechanical transfer of virions or contamination through the genital tract fluids during vaginal delivery. It is necessary that the diagnostic tests include an adequate range of biological samples from the mother and the newborn, such as amniotic fluid, umbilical cord blood, vaginal secretions, placenta, and neonatal nasopharyngeal swabs. PCR is the method of choice to isolate SARS-CoV-2 nucleic acids [241].

Maternal SARS-CoV-2 infection in the first and second trimesters of pregnancy increases the risk of early 


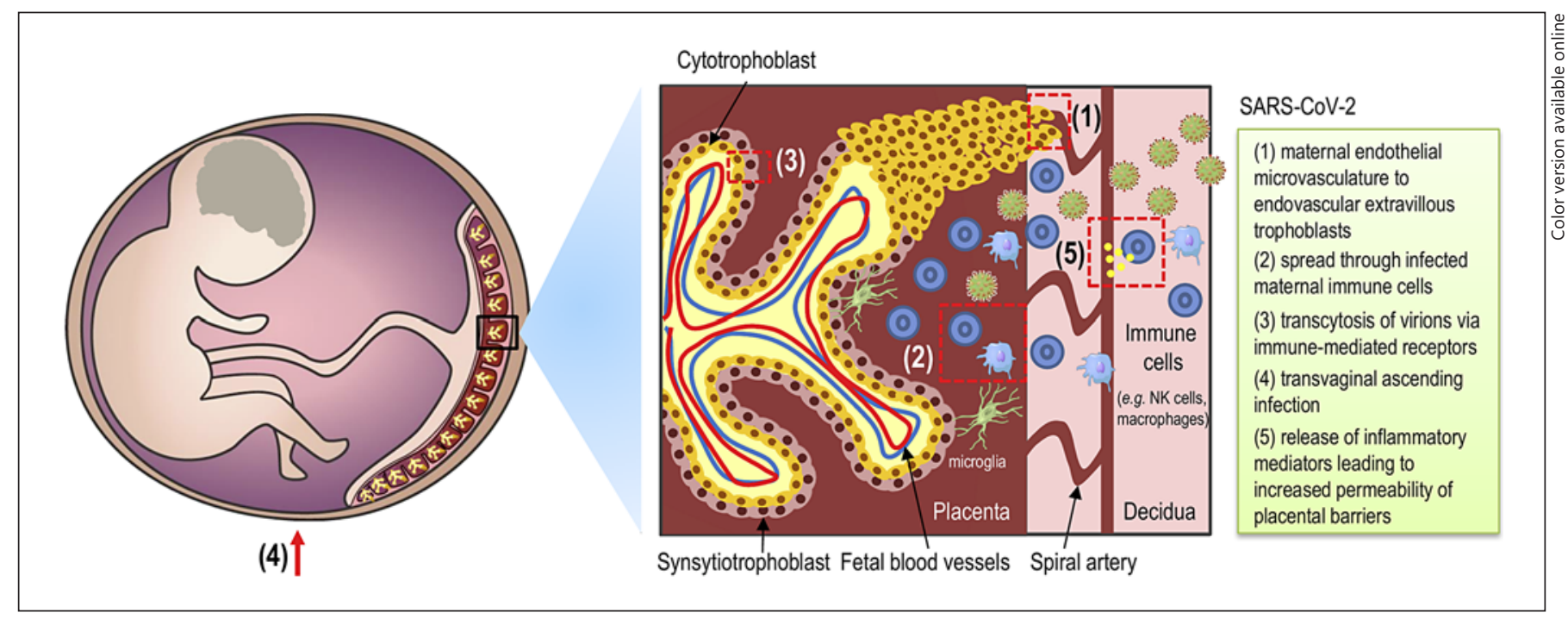

Fig. 3. Possible pathways for SARS-CoV-2 vertical transmission at the maternal-fetal interface. Similar to other pathogens, SARSCoV-2 infection during pregnancy could reach the placenta and impair the fetal development through different pathways. This schematic picture shows the fetus inside the intrauterine cavity (left panel), along with a magnification of the maternal-fetal interface with its main components such as placenta, decidua, spiral artery, fetal blood vessels, trophoblast cells (e.g., cytotrophoblast and syncytiotrophoblast), immune cells (e.g., NK cells and macrophages), and migrating microglia (middle panel). There are some possible pathways for SARS-CoV-2 vertical transmission crossing the maternal-fetal interface and were indicated by the numbers throughout the picture (dashed red square) and in the right panel: (1) through maternal endothelial microvasculature to endovascular extravillous trophoblasts; (2) spread through infected maternal immune cells; (3) transcytosis of virions via immune-mediated receptors; (4) transvaginal ascending infection; and (5) release of inflammatory mediators, leading to increased permeability of placental barriers. SARS-CoV-2, severe acute respiratory syndromerelated coronavirus 2 ; NK, natural killer. miscarriage, fetal death in utero, and growth retardation. A study published in 2004 during the SARS epidemic found a higher rate of miscarriage, premature delivery, and stunting but no evidence for vertical transmission of SARS-CoV-1 [112]. In addition, abnormally high mortality was not observed in pregnant women infected with SARS-CoV-2 compared to what had been observed during the epidemics of SARS-CoV-1 and MERS-CoV [242]. For the moment, no fetopathy has been described in fetuses or neonates whose mothers had COVID-19 [243].

During primary infections, virus circulation in the bloodstream, even for a short time, is an essential factor for its transplacental transport and maternal-fetal transmission through viral tropism toward the placenta [243]. Indeed, such a mechanism could be applied for the possible vertical transmission of SARS-CoV-2. The possible placental crossing by SARS-CoV-2 is similar to other pathogens, and the route for vertical transmission could occur by 5 typical pathways: (1) the maternal endothelial microvasculature to endovascular extravillous trophoblasts; (2) spreading through infected maternal im- mune cells; (3) transcytosis of virions via immune-mediated receptors; (4) transvaginal ascending infection; and (5) release of inflammatory mediators leading to increased permeability of placental barriers (Fig. 3) [244, 245].

Studies with placentas delivered from mothers with COVID-19 evaluated the presence of SARS-CoV-2 for RT-PCR but found no evidence for the virus. Histopathological analysis performed in 3 placentas also did not reveal tissue alterations [139, 235, 246-248]. To confirm vertical transmission, it has been proposed that detection of the virus by PCR in umbilical cord blood, neonatal blood collected within the first $12 \mathrm{~h}$ of birth, or amniotic fluid collected prior to rupture of membranes is needed [241, 249]. It is important to note that ACE2, the receptor for SARS-CoV-2, is present only at very low levels in the human placenta during the first trimester of pregnancy [250], while there are no data on the expression of this receptor in second and third trimester placentas [243].

Apparently, vertical transmission of SARS-CoV-2 is not frequent, although it cannot be, yet, completely dis- 
missed. Reports of neonatal infection with COVID-19 shortly after delivery suggest either transplacental migration or horizontal transmission through contact with maternal mucosa at delivery or during breastfeeding as the mode of viral migration $[14,239]$.

Another possibility for the virus to cross the placental barrier is to be carried by an infected blood cell. However, SARS-CoV-2, if able to enter into peripheral blood mononuclear cells, does not seem to replicate in these cells, such as SARS-CoV [243, 251]. Additionally, the resident macrophages of the lymph nodes express the ACE2 receptor, and in terminally ill patients, the virus is found in these cells but not in T or B lymphocytes [235, 252]. SARSCoV-1, which also uses the ACE2 receptor, is also found in alveolar macrophages [253]. Although no replication or transport of infectious viruses by macrophage monocytes has been demonstrated, lymph node and spleen macrophages can harbor the virus [243].

\section{Maternal-Fetal Interface and the Harmful Effects of SARS-CoV-2 Infection on the Fetus}

Viruses replicate in various cell types within the maternal-fetal interface. In the case of ZIKV, evidence of viral replication was identified in proliferating villus and Hofbauer cells (fetal macrophages) in the villous core [254]. Additionally, the ability of ZIKV to be transmitted sexually allows it to bypass the trophoblast layer via ascending infection of the amniochorionic membrane [255].

Findings reported by Jain et al. [256] have described 2 neonates born from SARS-CoV-2-positive women with diverse manifestations. They observed that neither infant was positive for SARS-CoV-2 infection by RTPCR [256]. These findings are similar to a previous study that demonstrated that out of 33 neonates born from women with SARS-CoV-2 infection, only 3 were found to be positive by RT-PCR at varied time periods after birth [257]. In another study case, 7 neonates born from SARS-CoV-2-infected women were found to be negative with diverse manifestations, including premature birth, fetal distress, and neonatal respiratory distress syndrome $[258,259]$.

A study by Egloff and colleagues [243] reported that patients were infected in late pregnancy and give birth a few days after infection. Regarding time, the mean gestational age was 37 weeks and 1 day, and the range was $30-40$ weeks and 2 days. Of 81 (69\%) newborns who were tested for SARS-CoV-2, $5(6 \%)$ had a positive result [236, 260]. Tests were performed more frequently with nasopharyngeal swabs in 46 neonates (57\%), followed by 16 breast milk (20\%) and throat swabs in 10 neonates (12\%) [261]. The tests were repeated; of 79 neonates, 49 (62\%) were subjected to a new test, and all neonates except 1 subsequently tested negative for SARS-CoV-2 [261]. Premature birth, defined as a gestational age of $<37$ weeks, was observed in $24(20 \%)$ newborns. In 47 neonates whose information on birth weight was disclosed, 42 (89\%) had adequate weight for their gestational age (AGA). Three (7\%) newborns were underweight for the gestational age (SGA), and 2 (4\%) newborns were overweight for their gestational age (SGA). In another study, 9 neonates (5\%) had respiratory dissipation or shortness of breath, depending on the complications. There has been $1 \%$ neonatal death [138]. A study carried out by Thomas et al. in 2020 observed that the newborn's mother had complications such as vaginal bleeding in the third trimester and a positive test for SARS-CoV-2 three days after cesarean delivery, when she first presented with symptoms of COVID-19 (fever). In the study, the newborn who died had a negative result for SARS-CoV-2 [261].

Walker et al. [249] stated that COVID-19 disease should not be an indication for cesarean delivery, differentiated feeding, or isolation of the mother's baby. C-sections should continue to be performed for normal obstetric indications. Mothers who breastfeed and stay with their babies should continue to observe COVID-19 hygiene precautions. There are many evidence supporting isolation between newborn and mother, in detriment of the beneficial contact of them [249].

\section{Conclusion}

Pregnancy may be a risk factor for respiratory virus infections. For example, during the H1N1 epidemic in 2009 , it was observed that pregnant women had a higher risk of complications, as they were 4 times more likely to be hospitalized than the rest of the population [262]. Pneumonia is one of the most prevalent non-obstetric infections in pregnant women, being one of the most common causes of maternal death. It also requires ventilatory support in 25\% of cases [263-265]. During pregnancy, morbidity and mortality from viral pneumonia are more serious than bacterial pneumonia, frequently causing premature rupture of membranes, stillbirth, intrauterine growth restriction, and premature birth [263].

So far, this does not seem to be the case for the current SARS-CoV-2 pandemic. In contrast, there is no evidence showing significant differences in the pathophysiology or
Neuroimmunomodulation 2021;28:1-21 DOI: $10.1159 / 000515556$
Granja et al. 
severity of the disease between pregnant and nonpregnant women. In fact, pregnant women generally showed mild to moderate degrees of infection, with most babies being born alive. This scenario calls attention to possible neurological consequences that can arise to babies who have been subject to an exacerbated maternal immune response to fight the virus.

The placenta is a physical and immunological defense against fetal infection. Maternal NK cells, deciduous macrophages, and $\mathrm{T}$ cells surround the placenta. Immune cells are vital in the remodeling and implantation of the placenta; deficiencies are associated with spontaneous abortion and other adverse pregnancy outcomes [266]. Although evidence shows that vertical transmission does not occur, infection by SARS-CoV-2 disturbs the maternal-fetal interface, changing immune cells signaling present there. This in turn leads to an increase in inflammatory cytokines that cross the placenta and can influence the neurodevelopment of the fetus. Therefore, it is important to evaluate and monitor these babies to assess whether COVID may induce neurological sequelae or psychiatric disease in the future.

\section{Statement of Ethics}

The article is exempt from approval by the Ethics Committee because it is a review article.

\section{Conflict of Interest Statement}

The authors have no conflicts of interest to declare.

\section{Funding Sources}

M.G.G., A.C.R.O., and C.S.F. receive CAPES fellowships. E.C.F. receives a fellowship from REDENEURIN - FAPERJ. This work was supported by grants from CAPES, FIOCRUZ, UFF, and INCT-NIM.

\section{Author Contributions}

M.G.G. and A.C.R.O. designed the study. M.G.G., A.C.R.O., A.P.G., and E.C.F. performed the bibliographic search and wrote the manuscript. C.S.F. prepared the figures, table, and wrote the manuscript. E.G.-A. and H.C.C.-F.-N. reviewed the manuscript. All authors have approved the final manuscript.

\section{References}

1 Guan Y, Peiris JS, Zheng B, Poon LL, Chan $\mathrm{KH}$, Zeng FY, et al. Molecular epidemiology of the novel coronavirus that causes severe acute respiratory syndrome. Lancet. 2004; 363(9403):99.

2 Drosten C, Günther S, Preiser W, Van der Werf S, Brodt HR, Becker S, et al. Identification of a novel coronavirus in patients with severe acute respiratory syndrome. $\mathrm{N}$ Engl J Med. 2003;348(20):1967.

3 Woo PCY, Lau SKP, Chu C, Chan K, Tsoi H, Huang $\mathrm{Y}$, et al. Characterization and complete genome sequence of a novel coronavirus, coronavirus HKU1, from patients with pneumonia. J Virol. 2005 Jan;79(2):884-95.

4 Lee N, Hui D, Wu A, Chan P, Cameron P, Joynt GM, et al. A major outbreak of severe acute respiratory syndrome in Hong Kong. N Engl J Med. 2003;348(20):1986.

5 Zaki AM, Van Boheemen S, Bestebroer TM, Osterhaus AD, Fouchier RA. Isolation of a novel coronavirus from a man with pneumonia in Saudi Arabia. N Engl J Med. 2012; 367(19): 1814.

6 Mubarak A, Alturaiki W, Hemida MG. Middle east respiratory syndrome coronavirus (MERS-CoV): infection, immunological response, and vaccine development. J Immunol Res. 2019 Apr 7;2019:6491738.

7 World Health Organization. Coronavirus Disease (COVID-19): Situation Dashboard. [Internet]. 2021. Available from: https://covid19.who.int/.
8 World Health Organization. Coronavirus disease (COVID-19) Weekly Epidemiological Update and Weekly Operational Update [Internet]. 2021. Available from: https://www. who.int/emergencies/diseases/novel-coronavirus-2019/situation-reports/.

9 Lu R, Zhao X, Li J, Niu P, Yang B, Wu H, et al. Genomic characterisation and epidemiology of 2019 novel coronavirus: implications for virus origins and receptor binding. Lancet. 2020 Feb 22;395(10224):564-74.

10 Robba C, Battaglini D, Pelosi P, Rocco PRM. Multiple organ dysfunction in SARS-CoV-2: MODS-CoV-2. Expert Rev Respir Med. 2020 Sep;14(9):865-8.

11 Huang C, Wang Y, Li X, Ren L, Zhao J, Hu Y, et al. Clinical features of patients infected with 2019 novel coronavirus in Wuhan, China. Lancet. 2020 Feb 15;395(10223):497-506.

12 Lippi G, Mattiuzzi C. Hemoglobin value may be decreased in patients with severe coronavirus disease 2019. Hematol Transfus Cell Ther. 2020 Apr-Jun;42(2):116-7.

13 Prochaska E, Jang M, Burd I. COVID-19 in pregnancy: placental and neonatal involvement. Am J Reprod Immunol. 2020 Nov; 84(5):e13306.

14 Mahyuddin A, Kanneganti A, Wong J, Dimri PS, Su L, Biswas A, et al. Mechanisms and evidence of vertical transmission of infections in pregnancy including SARS-CoV-2. Prenat Diagn. 2020 Dec;40(13):1655-70.
15 Schwartz DA, Graham AL. Potential maternal and infant outcomes from coronavirus 2019NCOV (SARS-CoV-2) infecting pregnant women: lessons from SARS, MERS, and other human coronavirus infections. Viruses. 2020 Feb 10;12(2):194.

16 Zabetakis I, Lordan R, Norton C, Tsoupras A. Covid-19: the inflammation link and the role of nutrition in potential mitigation. Nutrients. 2020 May 19;12(5):1466.

17 Conti P, Ronconi G, Caraffa A, Gallenga C, Ross R, Frydas I, et al. Induction of pro-inflammatory cytokines (IL-1 and IL-6) and lung inflammation by coronavirus-19 (COVI19 or SARS-CoV-2): anti-inflammatory strategies. J Biol Regul Homeost Agents. 2020 Mar-Apr;34(2):327-31.

18 Li G, Fan Y, Lai Y, Han T, Li Z, Zhou P, et al. Coronavirus infections and immune responses. J Med Virol. 2020 Apr;92(4):424-32.

19 Machado C, Gutierrez JV. Brainstem dysfunction in SARS-COV-2 infection can be a potential cause of respiratory distress (Review article) Design regularities of domestic interfaces for patients with Parkinson Disease (Regularidades para el diseño de interfaces domésticas para paci). 2020;2.

20 Chen G, Wu D, Guo W, Cao Y, Huang D, Wang $\mathrm{H}$, et al. Clinical and immunological features of severe and moderate coronavirus disease 2019. J Clin Invest. 2020 May;130(5): $2620-9$. 
21 Qin C, Zhou L, Hu Z, Zhang S, Yang S, Tao Y, et al. Dysregulation of immune response in patients with COVID-19 in Wuhan, China. Clin Infect Dis. 2020 Jul 28;71(15):762-8.

22 Chen L, Liu HG, Liu W, Liu J, Liu K, Shang J, et al. [Analysis of clinical features of 29 patients with 2019 novel coronavirus pneumonia]. Zhonghua Jie He He Hu Xi Za Zhi. 2020 Mar 12;43(3):203-8.

23 Liu T, Zhang J, Yang Y, Zhang L, Ma H, Li Z, et al. The potential role of IL-6 in monitoring coronavirus disease 2019. SSRN Electron J. 2020 Mar 10.

24 Sun D, Li H, Lu XX, Xiao H, Ren J, Zhang FR, et al. Clinical features of severe pediatric patients with coronavirus disease 2019 in Wuhan: a single center's observational study. World J Pediatr. 2020 Jun;16(3):251-9.

25 Gao Y, Li T, Han M, Li X, Wu D, Xu Y, et al. Diagnostic utility of clinical laboratory data determinations for patients with the severe COVID-19. J Med Virol. 2020 Jul;91(7):7916.

26 Raony Í, de Figueiredo CS, Pandolfo P, Giestal-de-Araujo E, Oliveira-Silva Bomfim P, Savino W. Psycho-neuroendocrine-immune interactions in COVID-19: potential impacts on mental health. Front Immunol. 2020 May 27;11:1170.

27 Catanzaro M, Fagiani F, Racchi M, Corsini E, Govoni S, Lanni C. Immune response in COVID-19: addressing a pharmacological challenge by targeting pathways triggered by SARS-CoV-2. Signal Transduct Target Ther. 2020 May 29;5(1):84.

28 Liao Y, Li X, Mou T, Zhou X, Li D, Wang L, et al. Distinct infection process of SARSCoV-2 in human bronchial epithelial cells line. J Med Virol. 2020 Nov;92(11):2830-8.

29 Butowt R, Bilinska K. SARS-CoV-2: olfaction, brain infection, and the urgent need for clinical samples allowing earlier virus detection. ACS Chem Neurosci. 2020 May 6;11(9): 1200-3.

30 Baig AM, Khaleeq A, Ali U, Syeda H. Evidence of the COVID-19 virus targeting the CNS: tissue distribution, host-virus interaction, and proposed neurotropic mechanisms. ACS Chem Neurosci. 2020 Apr 1;11(7):9958.

31 Yavarpour-Bali H, Ghasemi-Kasman M. Update on neurological manifestations of COVID-19. Life Sci. 2020 Sep 15;257:118063.

32 Tsivgoulis G, Palaiodimou L, Katsanos AH, Caso V, Köhrmann M, Molina C, et al. Neurological manifestations and implications of COVID-19 pandemic. Ther Adv Neurol Disord. 2020 Jun 9;13.

33 Ahmed MU, Hanif M, Ali MJ, Haider MA, Kherani D, Memon GM, et al. Neurological manifestations of COVID-19 (SARS-CoV-2): a review. Front Neurol. 2020 May 22;11:518.

34 Poyiadji N, Shahin G, Noujaim D, Stone M, Patel S, Griffith B. COVID-19-associated acute hemorrhagic necrotizing encephalopathy: CT and MRI features. Radiology. 2020 Aug;296(2):E119-20.
35 Aghagoli G, Gallo Marin B, Katchur NJ, Chaves-Sell F, Asaad WF, Murphy SA. Neurological involvement in COVID-19 and potential mechanisms: a review. Neurocrit Care. 2020 Jul 13:1-10.

36 Libbey JE, Kennett NJ, Wilcox KS, White HS, Fujinami RS. Interleukin-6, produced by resident cells of the central nervous system and infiltrating cells, contributes to the development of seizures following viral infection. J Virol. 2011 Jul;85(14):6913-22.

37 Singhi P. Infectious causes of seizures and epilepsy in the developing world. Dev Med Child Neurol. 2011;53(7):600.

38 Ye M, Ren Y, Lv T. Encephalitis as a clinical manifestation of COVID-19. Brain Behav Immun. 2020 Aug;88:945-6.

39 Mao L, Jin H, Wang M, Hu Y, Chen S, He Q, et al. Neurologic manifestations of hospitalized patients with coronavirus disease 2019 in Wuhan, China. JAMA Neurol. 2020 Jun 1; 77(6):683-90.

40 Gane SBC, Kelly C, Hopkins C. Isolated Sudden onset anosmia in COVID-19 infection. A novel syndrome? Rhinology. 2020 Jun 1; 58(3):229-301.

41 Hopkins C, Surda P, Kumar N. Presentation of new onset anosmia during the COVID-19 pandemic. Rhinology. 2020 Jun 1;58(3):295-8.

42 Lechien JR, Chiesa-Estomba CM, De Siati DR, Horoi M, Le Bon SD, Rodriguez A, et al. Olfactory and gustatory dysfunctions as a clinical presentation of mild-to-moderate forms of the coronavirus disease (COVID-19): a multicenter European study. Eur Arch Oto-Rhino-Laryngology. 2020 Aug; 277(8):2251-61.

43 Parma V, Ohla K, Veldhuizen MG, Niv MY, Kelly CE, Bakke AJ, et al. More than smell: COVID-19 is associated with severe impairment of smell, taste, and chemesthesis. Chem Senses. 2020 Oct; 45(7):609-22.

44 Bolay H, Gül A, Baykan B. COVID-19 is a real headache!. Headache. 2020 Jul;60(7):1415-21.

45 Brouwer MC, Ascione T, Pagliano P. Neurologic aspects of COVID-19: a concise review. Infez Med. 2020 Jun 1;28(Suppl 1):42-5.

46 Asadi-Pooya AA. Seizures associated with coronavirus infections. Seizure. 2020 Jul;79: 49-52.

47 Beyrouti R, Adams ME, Benjamin L, Cohen H, Farmer SF, Goh YY, et al. Characteristics of ischaemic stroke associated with $\mathrm{CO}$ VID-19. J Neurol Neurosurg Psychiatry. 2020 Aug;91(8):889-91.

48 Moriguchi T, Harii N, Goto J, Harada D, Sugawara $\mathrm{H}$, Takamino J, et al. A first case of meningitis/encephalitis associated with SARS-Coronavirus-2. Int J Infect Dis. 2020 May;94:55-8.

49 Rogers JP, Chesney E, Oliver D, Pollak TA, McGuire P, Fusar-Poli P, et al. Psychiatric and neuropsychiatric presentations associated with severe coronavirus infections: a systematic review and meta-analysis with comparison to the COVID-19 pandemic. Lancet Psychiatry. 2020 Jul;7(7):611-27.
50 Le Bouteiller P, Bensussan A. Up-and-down immunity of pregnancy in humans. F1000Res. 2017;6:1216.

51 Hsu P, Nanan RK. Innate and adaptive immune interactions at the fetal-maternal interface in healthy human pregnancy and pre-eclampsia. Front Immunol. 2014;5:125.

52 Glover LE, Crosby D, Thiruchelvam U, Harmon C, Chorcora CN, Wingfield MB, et al. Uterine natural killer cell progenitor populations predict successful implantation in women with endometriosis-associated infertility. Am J Reprod Immunol. 2018 Mar;79(3). Epub ahead of print.

53 Solders M, Gorchs L, Gidlöf S, Tiblad E, Lundell AC, Kaipe H. Maternal adaptive immune cells in decidua parietalis display a more activated and coinhibitory phenotype compared to decidua basalis. Stem Cells Int. 2017;2017: 8010961.

54 Yang F, Zheng Q, Jin L. Dynamic function and composition changes of immune cells during normal and pathological pregnancy at the maternal-fetal interface. Front Immunol. 2019 Oct 18;10:2317.

55 Mor G, Aldo P, Alvero AB. The unique immunological and microbial aspects of pregnancy. Nat Rev Immunol. 2017;17(8):469-82.

56 PrabhuDas M, Bonney E, Caron K, Dey S, Erlebacher A, Fazleabas A, et al. Immune mechanisms at the maternal-fetal interface: perspectives and challenges. Nat Immunol. 2015; 16(4):328.

57 Bulmer JN, Pace D, Ritson A. Immunoregulatory cells in human decidua: morphology, immunohistochemistry and function. Reprod Nutr Dev. 1988;28(6B):1599.

58 Abelius MS, Janefjord C, Ernerudh J, Berg G, Matthiesen L, Duchén K, et al. The placental immune milieu is characterized by a Th2- and anti-inflammatory transcription profile, regardless of maternal allergy, and associates with neonatal immunity. Am J Reprod Immunol. 2015;73(5):445.

59 Lash GE, Robson SC, Bulmer JN. Review: functional role of uterine natural killer (uNK) cells in human early pregnancy decidua. Placenta. 2010;31 Suppl:S87.

60 Helige C, Ahammer H, Moser G, Hammer A, Dohr G, Huppertz B, et al. Distribution of decidual natural killer cells and macrophages in the neighbourhood of the trophoblast invasion front: a quantitative evaluation. Hum Reprod. 2014;29(1):8.

61 Smith SD, Dunk CE, Aplin JD, Harris LK, Jones RL. Evidence for immune cell involvement in decidual spiral arteriole remodeling in early human pregnancy. Am J Pathol. 2009;174(5):1959.

62 Pijnenborg R, Vercruysse L, Hanssens M. The uterine spiral arteries in human pregnancy: facts and controversies. Placenta. 2006 SepOct:27(9-10):939-58.

63 Hazan AD, Smith SD, Jones RL, Whittle W, Lye SJ, Dunk CE. Vascular-leukocyte interactions: mechanisms of human decidual spiral artery remodeling in vitro. Am J Pathol. 2010; 177(2): 1017 . 
64 Wallace AE, Fraser R, Cartwright JE. Extravillous trophoblast and decidual natural killer cells: a remodelling partnership. Hum Reprod Update. 2012;18(4):458.

65 Saito S, Nishikawa K, Morii T, Enomoto M, Narita N, Motoyoshi K, et al. Cytokine production by CD16-CD56bright natural killer cells in the human early pregnancy decidua. Int Immunol. 1993;5(5):559-63.

66 Hanna J, Goldman-Wohl D, Hamani Y, Avraham I, Greenfield C, Natanson-Yaron S, et al. Decidual NK cells regulate key developmental processes at the human fetal-maternal interface. Nat Med. 2006;12(9):1065.

67 Jokhi PP, King A, Loke YW. Production of granulocyte-macrophage colony-stimulating factor by human trophoblast cells and by decidual large granular lymphocytes. Hum Reprod. 1994 Sep;9(9):1660-9.

68 Lash GE, Schiessl B, Kirkley M, Innes BA, Cooper A, Searle RF, et al. Expression of angiogenic growth factors by uterine natural killer cells during early pregnancy. J Leukoc Biol. 2006;80(3):572.

69 Naruse K, Lash GE, Innes BA, Otun HA, Searle RF, Robson SC, et al. Localization of matrix metalloproteinase (MMP)-2, MMP-9 and tissue inhibitors for MMPs (TIMPs) in uterine natural killer cells in early human pregnancy. Hum Reprod. 2009;24(3):553-61.

70 Rajagopalan S, Bryceson YT, Kuppusamy SP, Geraghty DE, Van Der Meer A, Joosten I, et al. Activation of NK cells by an endocytosed receptor for soluble HLA-G. PLoS Biol. 2006; $4(1): e 9$.

71 Renaud SJ, Graham CH. The role of macrophages in utero-placental interactions during normal and pathological pregnancy. Immunol Invest. 2008;37(5):535.

72 Bulmer JN, Johnson PM. Macrophage populations in the human placenta and amniochorion. Clin Exp Immunol. 1984;57(2):393.

73 Bulmer JN, Morrison L, Smith JC. Expression of class II MHC gene products by macrophages in human uteroplacental tissue. Immunology. 1988;63(4):707.

74 Reister F, Frank HG, Kingdom JC, Heyl W, Kaufmann P, Rath W, et al. Macrophage-induced apoptosis limits endovascular trophoblast invasion in the uterine wall of preeclamptic women. Lab Invest. 2001;81(8): 1143.

75 Mor G, Abrahams VM. Potential role of macrophages as immunoregulators of pregnancy. Reprod Biol Endocrinol. 2003;1:119.

76 Nagamatsu T, Schust DJ. The immunomodulatory roles of macrophages at the maternalfetal interface. Reprod Sci. 2010 Mar;17(3) 209-18.

77 Heikkinen J, Möttönen M, Komi J, Alanen A, Lassila O. Phenotypic characterization of human decidual macrophages. Clin Exp Immunol. 2003;131(3):498

78 Ito A, Hiro D, Ojima Y, Mori Y. Spontaneous production of interleukin-1-like factors from pregnant rabbit uterine cervix. Am J Obstet Gynecol. 1988;159(1):261-5.
79 Hamilton S, Oomomian Y, Stephen G, Shynlova O, Tower CL, Garrod A, et al. Macrophages infiltrate the human and rat decidua during term and preterm labor: evidence that decidual inflammation precedes labor. Biol Reprod. 2012;86(2):39.

80 Shynlova O, Nedd-Roderique T, Li Y, Dorogin A, Lye SJ. Myometrial immune cells contribute to term parturition, preterm labour and post-partum involution in mice. J Cell Mol Med. 2013;17(1):90.

81 Mor G, Cardenas I, Abrahams V, Guller S. Inflammation and pregnancy: the role of the immune system at the implantation site. Ann N Y Acad Sci. 2011;1221:80.

82 McIntire RH, Ganacias KG, Hunt JS. Programming of human monocytes by the uteroplacental environment. Reprod Sci. 2008; 15(5):437.

83 Lidström C, Matthiesen L, Berg G, Sharma S, Ernerudh J, Ekerfelt C. Cytokine secretion patterns of NK cells and macrophages in early human pregnancy decidua and blood: implications for suppressor macrophages in decidua. Am J Reprod Immunol. 2003;50(6): 444.

84 Parhar RS, Yagel S, Lala PK. PGE2-mediated immunosuppression by first trimester human decidual cells blocks activation of maternal leukocytes in the decidua with potential antitrophoblast activity. Cell Immunol. 1989; 120(1):61.

85 Kämmerer U, Eggert AO, Kapp M, McLellan AD, Geijtenbeek TB, Dietl J, et al. Unique appearance of proliferating antigen-presenting cells expressing DC-SIGN (CD209) in the decidua of early human pregnancy. Am J Pathol. 2003;162(3):887.

86 Darmochwal-Kolarz DA, Kludka-Sternik M, Chmielewski T, Kolarz B, Rolinski J, Leszczynska-Gorzelak B, et al. The expressions of CD200 and CD200R molecules on myeloid and lymphoid dendritic cells in pre-eclampsia and normal pregnancy. Am J Reprod Immunol. 2012;67(6):474.

87 Mellman I. Dendritic cells: master regulators of the immune response. Cancer Immunol Res. 2013;1(3):145.

88 Hsu P, Santner-Nanan B, Dahlstrom JE, Fadia M, Chandra A, Peek M, et al. Altered decidual DC-SIGN+ antigen-presenting cells and impaired regulatory $\mathrm{T}$-cell induction in preeclampsia. Am J Pathol. 2012;181(6):2149.

89 Huang Y, Zhu XY, Du MR, Li DJ. Human trophoblasts recruited $\mathrm{T}$ lymphocytes and monocytes into decidua by secretion of chemokine CXCL16 and interaction with CXCR6 in the first-trimester pregnancy. J Immunol. 2008;180(4):2367.

90 Jin LP, Chen QY, Zhang T, Guo PF, Li DJ. The $\mathrm{CD} 4+\mathrm{CD} 25$ bright regulatory $\mathrm{T}$ cells and CTLA-4 expression in peripheral and decidual lymphocytes are down-regulated in human miscarriage. Clin Immunol. 2009;133(3):402.
91 Gomez-Lopez N, Vadillo-Perez L, Hernandez-Carbajal A, Godines-Enriquez M, Olson DM, Vadillo-Ortega F. Specific inflammatory microenvironments in the zones of the fetal membranes at term delivery. Am J Obstet Gynecol. 2011;205(3):235.

92 Miller D, Gershater M, Slutsky R, Romero R Gomez-Lopez N. Maternal and fetal T cells in term pregnancy and preterm labor. Cell Mol Immunol. 2020 Jul;17(7):693-704.

93 Bilbo SD, Schwarz JM. The immune system and developmental programming of brain and behavior. Front Neuroendocrinol. 2012; 33(3):267.

94 Deverman BE, Patterson PH. Cytokines and CNS Development. Neuron. 2009;64(1):61.

95 Skaper SD. Neurotrophic factors: an overview. Methods Mol Biol. 2018;1727:1-17.

96 Oppenheim RW. Cell death during development of the nervous system. Annu Rev Neurosci. 1991 Mar;14(1):453-501.

97 Henderson CE. Role of neurotrophic factors in neuronal development. Curr Opin Neurobiol. 1996 Feb;6(1):64-70.

98 Nawa $\mathrm{H}$, Takei $\mathrm{N}$. Recent progress in animal modeling of immune inflammatory processes in schizophrenia: implication of specific cytokines. Neurosci Res. 2006;56(1):2.

99 Schepanski S, Buss C, Hanganu-Opatz IL, Arck PC. Prenatal immune and endocrine modulators of offspring's brain development and cognitive functions later in life. Front Immunol. 2018 Sep 26;9:2186.

100 Boschen KE, Klintsova AY. Neurotrophins in the brain: interaction with alcohol exposure during development. Vitam Horm. 2017;104:197.

101 Thion MS, Ginhoux F, Garel S. Microglia and early brain development: an intimate journey. Science. 2018 Oct 12;362(6411): $185-9$.

102 Gehrmann J. Microglia: a sensor to threats in the nervous system? Res Virol. 1996; 147(2-3):79-88.

103 Cuadros MA, Navascués J. The origin and differentiation of microglial cells during development. Prog Neurobiol. 1998 Oct;56(2): 173-89.

104 Yuan TF, Hou G, Zhao Y, Arias-Carrión O. Commentary: the effects of psychological stress on microglial cells in the brain. CNS Neurol Disord Drug Targets. 2015;14(3): 304-8.

105 Ginhoux F, Lim S, Hoeffel G, Low D, Huber T. Origin and differentiation of microglia. Front Cell Neurosci. 2013 Apr 17;7:45-14.

106 Chan WY, Kohsaka S, Rezaie P. The origin and cell lineage of microglia: new concepts. Brain Res Rev. 2007;53(2):344

107 Kaur C, Ling EA, Wong WC. Origin and fate of neural macrophages in a stab wound of the brain of the young rat. J Anat. 1987;154: 215 .

108 Mosser CA, Baptista S, Arnoux I, Audinat E. Microglia in CNS development: shaping the brain for the future. Prog Neurobiol. 2017 Feb-Mar;149-150:1-20.
Maternal-Fetal SARS-CoV-2

Transmission: Effects on the Fetus
Neuroimmunomodulation 2021:28:1-21 
109 Sierra A, Navascués J, Cuadros MA, Calvente R, Martín-Oliva D, Ferrer-Martín RM, et al. Expression of inducible nitric oxide synthase (iNOS) in microglia of the developing quail retina. PLoS One. 2014;9(8):e1060485.

110 Wang CC, Wu CH, Shieh JY, Wen CY. Microglial distribution and apoptosis in fetal rat brain. Brain Res Dev Brain Res. 2002; 139(2):337.

111 Kourtis AP, Read JS, Jamieson DJ. Pregnancy and infection. N Engl J Med. 2014; 370(23):2211.

112 Wong SF, Chow KM, Leung TN, Ng WF, Ng TK, Shek CC, et al. Pregnancy and perinatal outcomes of women with severe acute respiratory syndrome. Am J Obstet Gynecol. 2004;191(1):292-7.

113 Estes ML, McAllister AK. IMMUNOLOGY. Maternal TH17 cells take a toll on baby's brain. Science. 2016;351(6276):919.

114 Colón DF, Wanderley CW, Franchin M, Silva $\mathrm{CM}$, Hiroki $\mathrm{CH}$, Castanheira FVS, et al. Neutrophil extracellular traps (NETs) exacerbate severity of infant sepsis. Crit Care. 2019 Apr 8;23(1):113.

115 Czaikoski PG, Mota JM, Nascimento DC, Sônego F, Castanheira FV, Melo PH, et al. Neutrophil extracellular traps induce organ damage during experimental and clinical sepsis. PLoS One. 2016;11(2):e0148142.

116 Li RHL, Tablin F. A comparative review of neutrophil extracellular traps in sepsis. Front Vet Sci. 2018 Nov 28;5:291.

117 Veras FP, Pontelli M, Silva C, Toller-Kawahisa J, Lima Mde, Nascimento D, et al. SARS-CoV-2 triggered neutrophil extracellular traps (NETs) mediate COVID-19 pathology. J Exp Med. 2020 Dec 7;217(12): e20201129.

118 Zuo Y, Yalavarthi S, Shi H, Gockman K, Zuo M, Madison JA, et al. Neutrophil extracellular traps (NETs) as markers of disease severity in COVID-19. medRxiv. 2020 Apr 14. Preprint.

119 Yan J, Guo J, Fan C, Juan J, Yu X, Li J, et al. Coronavirus disease 2019 in pregnant women: a report based on 116 cases. Am J Obstet Gynecol. 2020 Jul;223(1):111.e1-4.

120 Chen H, Guo J, Wang C, Luo F, Yu X, Zhang $\mathrm{W}$, et al. Clinical characteristics and intrauterine vertical transmission potential of COVID-19 infection in nine pregnant women: a retrospective review of medical records. Lancet. 2020 Mar 7;395(10226):80915.

121 Liu D, Li L, Wu X, Zheng D, Wang J, Yang $L$, et al. Pregnancy and perinatal outcomes of women with coronavirus disease (COVID-19) pneumonia: a preliminary analysis. AJR Am J Roentgenol. 2020 Jul;215(1):12732.

122 Wu Y, Liu C, Dong L, Zhang C, Chen Y, Liu J, et al. Coronavirus disease 2019 among pregnant Chinese women: case series data on the safety of vaginal birth and breastfeeding. BJOG. 2020 Aug;127(9):1109-15.
123 Narang K, Enninga EAL, Gunaratne MDSK, Ibirogba ER, Trad ATA, Elrefaei A, et al. SARS-CoV-2 infection and COVID-19 during pregnancy: a multidisciplinary review. Mayo Clin Proc. 2020 Aug;95(8):1750-65.

124 Malinowski AK, Noureldin A, Othman M. COVID-19 susceptibility in pregnancy: immune/inflammatory considerations, the role of placental ACE- 2 and research considerations. Reprod Biol. 2020;20(4):568-72.

125 Wenling Y, Junchao Q, Xiao Z, Ouyang S. Pregnancy and COVID-19: management and challenges. Rev Inst Med Trop Sao Paulo. 2020;62:e62.

126 Hosier H, Farhadian SF, Morotti RA, Deshmukh U, Lu-Culligan A, Campbell KH, et al. SARS-CoV-2 infection of the placenta. J Clin Invest. 2020 Sep 1;130(9):4947-53.

127 Chen S, Liao E, Cao D, Gao Y, Sun G, Shao Y. Clinical analysis of pregnant women with 2019 novel coronavirus pneumonia. J Med Virol. 2020 Sep;92(9):1556-61.

128 Wang Z, Wang Z, Xiong G. Clinical characteristics and laboratory results of pregnant women with COVID-19 in Wuhan, China. Int J Gynecol Obstet. 2020 Sep;150(3):312-7.

129 Mohr-Sasson A, Chayo J, Bart Y, Meyer R, Sivan E, Mazaki-Tovi S, et al. Laboratory characteristics of pregnant compared to non-pregnant women infected with SARSCoV-2. Arch Gynecol Obstet. 2020 Sep; 302(3):629-34.

130 Akhtar H, Patel C, Abuelgasim E, Harky A. COVID-19 (SARS-CoV-2) infection in pregnancy: a systematic review. Gynecol Obstet Invest. 2020;85(4):295-603.

131 Liu H, Liu F, Li J, Zhang T, Wang D, Lan W. Clinical and CT imaging features of the COVID-19 pneumonia: focus on pregnant women and children. J Infect. 2020 May; 80(5):e7-13.

132 Giakoumelou S, Wheelhouse N, Cuschieri K, Entrican G, Howie SEM, Horne AW. The role of infection in miscarriage. Hum Reprod Update. 2016 Jan-Feb;22(1):116-33.

133 Baud D, Greub G, Favre G, Gengler C, Jaton $\mathrm{K}$, Dubruc E, et al. Second-trimester miscarriage in a pregnant woman with SARSCoV-2 infection. JAMA. 2020 Jun 2;323(21): 2198-200

134 Hosier H, Farhadian SF, Morotti RA, Deshmukh U, Lu-Culligan A, Campbell KH, et al. SARS-CoV-2 infection of the placenta. J Clin Invest. 2020 Sep 1;130(9):4947-53.

135 Sherer ML, Lei J, Creisher P, Jang M, Reddy $\mathrm{R}$, Voegtline K, et al. Dysregulated immunity in SARS-CoV-2 infected pregnant women. medRxiv. 2020 Nov 16. Preprint.

136 Straughen JK, Misra DP, Divine G, Shah R, Perez G, VanHorn S, et al. The association between placental histopathology and autism spectrum disorder. Placenta. 2017;57:183.

137 Raghavan R, Helfrich BB, Cerda SR, Ji Y, Burd I, Wang G, et al. Preterm birth subtypes, placental pathology findings, and risk of neurodevelopmental disabilities during childhood. Placenta. 2019 Aug;83:17-25.
138 Zhu H, Wang L, Fang C, Peng S, Zhang L, Chang G, et al. Clinical analysis of 10 neonates born to mothers with $2019-\mathrm{nCoV}$ pneumonia. Transl Pediatr. 2020 Feb;9(1): 51-60.

139 Wang X, Zhou Z, Zhang J, Zhu F, Tang Y, Shen X. A case of 2019 Novel Coronavirus in a pregnant woman with preterm delivery. Clin Infect Dis. 2020 Jul 28;71(15):844-6.

140 Giugliano S, Petroff MG, Warren BD, Jasti S, Linscheid C, Ward A, et al. Hepatitis C virus sensing by human trophoblasts induces innate immune responses and recruitment of maternal NK cells: potential implications for limiting vertical transmission. J Immunol. 2015 Oct 15;195(8):3737-47.

141 Cardenas I, Mor G, Aldo P, Lang SM, Stabach P, Sharp A, et al. Placental viral infection sensitizes to endotoxin-induced preterm labor: a double hit hypothesis. Am J Reprod Immunol. 2011;65(2):110.

142 Gomez-Lopez N, StLouis D, Lehr MA, Sanchez-Rodriguez EN, Arenas-Hernandez M. Immune cells in term and preterm labor. Cell Mol Immunol. 2014;11(6):571.

143 Wu C, Yang W, Wu X, Zhang T, Zhao Y, Ren $\mathrm{W}$, et al. Clinical manifestation and laboratory characteristics of SARS-CoV-2 infection in pregnant women. Virol Sin. 2020; 35(3):305.

144 Rajewska A, Mikołajek-Bedner W, Lebdowicz-Knul J. COVID-19 and pregnancy: where are we now? A review. J Perinat Med. 2020 Jun 25;48(5):428-34.

145 Diriba K, Awulachew E, Getu E. The effect of coronavirus infection (SARS-CoV-2, MERS-CoV, and SARS-CoV) during pregnancy and the possibility of vertical maternal-fetal transmission: a systematic review and meta-analysis. Eur J Med Res. 2020 Sep 4;25(1):39.

146 Zimmer A, Youngblood A, Adnane A, Miller BJ, Goldsmith DR. Prenatal exposure to viral infection and neuropsychiatric disorders in offspring: a review of the literature and recommendations for the COVID-19 pandemic. Brain Behav Immun. 2021 Jan;91:756-70.

147 Fried M, Kurtis JD, Swihart B, Pond-Tor S, Barry A, Sidibe Y, et al. Systemic inflammatory response to malaria during pregnancy is associated with pregnancy loss and preterm delivery. Clin Infect Dis. 2017;65(10):1729.

148 Yockey LJ, Iwasaki A. Interferons and proinflammatory cytokines in pregnancy and fetal development. Immunity. 2018 Sep 18; 49(3):397-412.

149 Solano ME, Holmes MC, Mittelstadt PR, Chapman KE, Tolosa E. Antenatal endogenous and exogenous glucocorticoids and their impact on immune ontogeny and longterm immunity. Semin Immunopathol. 2016;38(6):739.

150 Behura SK, Dhakal P, Kelleher AM, Balboula A, Patterson A, Spencer TE. The brainplacental axis: therapeutic and pharmacological relevancy to pregnancy. Pharmacol Res. 2019 Nov; 149:104468. 
151 Voltolini C, Petraglia F. Neuroendocrinology of pregnancy and parturition. Handb Clin Neurol. 2014;124:17.

152 Okabe H, Makino S, Kato K, Matsuoka K, Seki H, Takeda S. The effect of progesterone on genes involved in preterm labor. J Reprod Immunol. 2014;104-105:80.

153 Arck PC, Rücke M, Rose M, Szekeres-Bartho J, Douglas AJ, Pritsch M, et al. Early risk factors for miscarriage: a prospective cohort study in pregnant women. Reprod Biomed Online. 2008;17(1):101.

154 Hierweger AM, Engler JB, Friese MA, Reichardt HM, Lydon J, DeMayo F, et al. Progesterone modulates the T-cell response via glucocorticoid receptor-dependent pathways. Am J Reprod Immunol. 2019 Feb; 81(2):e13084.

155 Lissauer D, Eldershaw SA, Inman CF, Coomarasamy A, Moss PA, Kilby MD. Progesterone promotes maternal-fetal tolerance by reducing human maternal $\mathrm{T}$-cell polyfunctionality and inducing a specific cytokine profile. Eur J Immunol. 2015;45(10): 2858.

156 Littauer EQ, Esser ES, Antao OQ, Vassilieva EV, Compans RW, Skountzou I. H1N1 influenza virus infection results in adverse pregnancy outcomes by disrupting tissuespecific hormonal regulation. PLoS Pathog. 2017 Nov 27;13(11):e1006757.

157 Moisiadis VG, Matthews SG. Glucocorticoids and fetal programming part 2: mechanisms. Nat Rev Endocrinol. 2014;10(7):403.

158 Holmes MC, Abrahamsen CT, French KL, Paterson JM, Mullins JJ, Seckl JR. The mother or the fetus? $11 \beta$-hydroxysteroid dehydrogenase type 2 null mice provide evidence for direct fetal programming of behavior by endogenous glucocorticoids. J Neurosci. 2006 Apr 5;26(14):3840-4.

159 Seckl JR, Holmes MC. Mechanisms of disease: glucocorticoids, their placental metabolism and fetal "programming" of adult pathophysiology. Nat Clin Pract Endocrinol Metab. 2007 Jun;3(6):479-88.

160 Hsiao EY, Patterson PH. Placental regulation of maternal-fetal interactions and brain development. Dev Neurobiol. 2012;72(10): 1317.

161 Ozaki K, Kato D, Ikegami A, Hashimoto A, Sugio S, Guo Z, et al. Maternal immune activation induces sustained changes in fetal microglia motility. Sci Rep. 2020 Dec 7; 10(1):21378

162 Fatemi SH, Folsom TD, Rooney RJ, Mori S, Kornfield TE, Reutiman TJ, et al. The viral theory of schizophrenia revisited: abnormal placental gene expression and structural changes with lack of evidence for $\mathrm{H} 1 \mathrm{~N} 1 \mathrm{viral}$ presence in placentae of infected mice or brains of exposed offspring. Neuropharmacology. 2012;62(3):1290.

163 Mauvais-Jarvis F, Klein SL, Levin ER. Estradiol, progesterone, immunomodulation, and COVID-19 outcomes. Endocrinology. 2020 Sep 1;161(9):bqaa127.
164 Berhan Y. What immunological and hormonal protective factors lower the risk of COVID-19 related deaths in pregnant women? J Reprod Immunol. 2020 Nov; 142: 103180.

165 Lautarescu A, Craig MC, Glover V. Prenatal stress: effects on fetal and child brain development. Int Rev Neurobiol. 2020;150:17-40.

166 Faa G, Manchia M, Pintus R, Gerosa C, Marcialis MA, Fanos V. Fetal programming of neuropsychiatric disorders. Birth Defects Res C Embryo Today. 2016;108(3):207-23.

167 Rasmussen JM, Graham AM, Entringer S, Gilmore JH, Styner M, Fair DA, et al. Maternal Interleukin-6 concentration during pregnancy is associated with variation in frontolimbic white matter and cognitive development in early life. Neuroimage. 2019 Jan 15;185:825-35.

168 Spann MN, Monk C, Scheinost D, Peterson BS. Maternal immune activation during the third trimester is associated with neonatal functional connectivity of the salience network and fetal to toddler behavior. J Neurosci. 2018 Mar 14;38(11):2877-86.

169 Marques AH, Bjørke-Monsen AL, Teixeira AL, Silverman MN. Maternal stress, nutrition and physical activity: impact on immune function, CNS development and psychopathology. Brain Res. 2015;1617:28-46.

170 Marques AH, O'Connor TG, Roth C, Susser E, Bjørke-Monsen AL. The influence of maternal prenatal and early childhood nutrition and maternal prenatal stress on offspring immune system development and neurodevelopmental disorders. Front Neurosci. 2013 Jul 31;7:120.

171 Van den Bergh BRH, van den Heuvel MI, Lahti M, Braeken M, de Rooij SR, Entringer $S$, et al. Prenatal developmental origins of behavior and mental health: the influence of maternal stress in pregnancy. Neurosci Biobehav Rev. 2020 Oct;117:26-64.

172 Bennett GA, Palliser HK, Shaw JC, Palazzi KL, Walker DW, Hirst JJ. Maternal stress in pregnancy affects myelination and neurosteroid regulatory pathways in the guinea pig cerebellum. Stress. 2017;20(6):1-9.

173 Allswede DM, Buka SL, Yolken RH, Torrey EF, Cannon TD. Elevated maternal cytokine levels at birth and risk for psychosis in adult offspring. Schizophr Res. 2016;172(1-3):41.

174 Brown AS, Hooton J, Schaefer CA, Zhang H, Petkova E, Babulas V, et al. Elevated maternal interleukin-8 levels and risk of schizophrenia in adult offspring. Am J Psychiatry. 2004;161(5):889.

175 Dozmorov MG, Bilbo SD, Kollins SH, Zucker N, Do EK, Schechter JC, et al. Associations between maternal cytokine levels during gestation and measures of child cognitive abilities and executive functioning. Brain Behav Immun. 2018 May;70:390-7.

176 Graham AM, Rasmussen JM, Rudolph MD, Heim CM, Gilmore JH, Styner M, et al. Maternal systemic interleukin-6 during pregnancy is associated with newborn amygdala phenotypes and subsequent behavior at 2 years of age. Biol Psychiatry. 2018 Jan 15; 83(2):109-19.

177 Beversdorf DQ, Stevens HE, Jones KL. Prenatal stress, maternal immune dysregulation, and their association with autism spectrum disorders. Curr Psychiatry Rep. 2018 Aug 9;20(9):76.

178 Varcin KJ, Alvares GA, Uljarević M, Whitehouse AJO. Prenatal maternal stress events and phenotypic outcomes in autism spectrum disorder. Autism Res. 2017;10(11): 1866-77.

179 Say GN, Karabekiroğlu K, Babadağı Z, Yüce M. Maternal stress and perinatal features in autism and attention deficit/hyperactivity disorder. Pediatr Int. 2016;58(4):265-9.

180 Betts KS, Williams GM, Najman JM, Alati R The relationship between maternal depressive, anxious, and stress symptoms during pregnancy and adult offspring behavioral and emotional problems. Depress Anxiety. 2015;32(2):82.

181 St-Hilaire A, Steiger H, Liu A, Laplante DP, Thaler L, Magill T, et al. A prospective study of effects of prenatal maternal stress on later eating-disorder manifestations in affected offspring: preliminary indications based on the project ice storm cohort. Int J Eat Disord. 2015;48(5):512.

182 O'Donnell KJ, Glover V, Barker ED, O'Connor TG. The persisting effect of maternal mood in pregnancy on childhood psychopathology. Dev Psychopathol. 2014 May; 26(2):393-403.

183 Leis JA, Heron J, Stuart EA, Mendelson T. Associations between maternal mental health and child emotional and behavioral problems: does prenatal mental health matter? J Abnorm Child Psychol. 2014;42(1):161.

184 Zhu P, Hao JH, Tao RX, Huang K, Jiang XM, Zhu YD, et al. Sex-specific and time-dependent effects of prenatal stress on the early behavioral symptoms of ADHD: a longitudinal study in China. Eur Child Adolesc Psychiatry. 2015;24(9):1139.

185 Lipner E, Murphy SK, Ellman LM. Prenatal maternal stress and the cascade of risk to schizophrenia spectrum disorders in offspring. Curr Psychiatry Rep. 2019 Sep 14; 21(10):99.

186 Le Gouez A, Benachi A, Mercier FJ. Fever and pregnancy. Anaesth Crit Care Pain Med. 2016;35(Suppl 1):S5-12.

187 Edwards MJ. Review: hyperthermia and fever during pregnancy. Birth Defects Res Part A Clin Mol Teratol. 2006;76(7):507.

188 Edwards MJ, Saunders RD, Shiota K. Effects of heat on embryos and foetuses. Int J Hyperthermia. 2003 May-Jun;19(3):295-324.

189 Dreier JW, Andersen AM, Berg-Beckhoff G. Systematic review and meta-analyses: fever in pregnancy and health impacts in the offspring. Pediatrics. 2014;133(3):e674.

190 Ziskin MC, Morrissey J. Thermal thresholds for teratogenicity, reproduction, and development. Int J Hyperthermia. 2011;27(4):374 
191 Werenberg Dreier J, Nybo Andersen AM, Hvolby A, Garne E, Kragh Andersen P, Berg-Beckhoff G. Fever and infections in pregnancy and risk of attention deficit/hyperactivity disorder in the offspring. J Child Psychol Psychiatry. 2016;57(4):540-8.

192 Flinkkilä E, Keski-Rahkonen A, Marttunen M, Raevuori A. Prenatal inflammation, infections and mental disorders. Psychopathology. 2016;49(5):317-33.

193 Zerbo O, Iosif AM, Walker C, Ozonoff S, Hansen RL, Hertz-Picciotto I. Is maternal influenza or fever during pregnancy associated with autism or developmental delays? Results from the CHARGE (Childhood Autism Risks from Genetics and Environment) study. J Autism Dev Disord. 2013;43(1):25.

194 Atladóttir HÓ, Henriksen TB, Schendel DE, Parner ET. Autism after infection, febrile episodes, and antibiotic use during pregnancy: an exploratory study. Pediatrics. 2012; 130(6): e1447.

195 Yang X, Yu Y, Xu J, Shu H, Xia J, Liu H, et al. Clinical course and outcomes of critically ill patients with SARS-CoV-2 pneumonia in Wuhan, China: a single-centered, retrospective, observational study. Lancet Respir Med. 2020 May;8(5):475-81.

196 Ruan Q, Yang K, Wang W, Jiang L, Song J. Clinical predictors of mortality due to COVID-19 based on an analysis of data of 150 patients from Wuhan, China. Intensive Care Med. 2020 May;46(5):846-8.

197 Tan L, Wang Q, Zhang D, Ding J, Huang Q, Tang YQ, et al. Lymphopenia predicts disease severity of COVID-19: a descriptive and predictive study. Signal Transduct Target Ther. 2020;5(1):16-8

198 Mehta P, McAuley DF, Brown M, Sanchez E, Tattersall RS, Manson JJ. COVID-19: consider cytokine storm syndromes and immunosuppression. Lancet. 2020 Mar 28; 395(10229):1033-34.

199 Ye Q, Wang B, Mao J. The pathogenesis and treatment of the 'Cytokine Storm' in COVID-19. J Infect. 2020 Jun;80(6):607-13.

200 Vaninov N. In the eye of the COVID-19 cytokine storm. Nat Rev Immunol. 2020 May; 20(5):277.

201 Henderson LA, Canna SW, Schulert GS, Volpi S, Lee PY, Kernan KF, et al. On the alert for cytokine storm: immunopathology in COVID-19. Arthritis Rheumatol. 2020 Jul;72(7):1059-63.

202 Ye Q, Wang B, Mao J. Cytokine storm in COVID-19 and treatment. J Infect. 2020.

203 Jones KL, Croen LA, Yoshida CK, Heuer L, Hansen R, Zerbo O, et al. Autism with intellectual disability is associated with increased levels of maternal cytokines and chemokines during gestation. Mol Psychiatry. 2017; 22(2):273

204 Brown AS, Begg MD, Gravenstein S, Schaefer CA, Wyatt RJ, Bresnahan M, et al. Serologic evidence of prenatal influenza in the etiology of schizophrenia. Arch Gen Psychiatry. 2004;61(8):774.
205 Patterson PH. Immune involvement in schizophrenia and autism: etiology, pathology and animal models. Behav Brain Res. 2009;204(2):313.

206 Brown AS, Sourander A, Hinkka-Yli-Salomäki S, McKeague IW, Sundvall J, Surcel HM. Elevated maternal C-reactive protein and autism in a national birth cohort. Mol Psychiatry. 2014;19(2):259.

207 Buka SL, Tsuang MT, Torrey EF, Klebanoff MA, Wagner RL, Yolken RH. Maternal cytokine levels during pregnancy and adult psychosis. Brain Behav Immun. 2001;15(4): 411.

208 Ellman LM, Deicken RF, Vinogradov S, Kremen WS, Poole JH, Kern DM, et al. Structural brain alterations in schizophrenia following fetal exposure to the inflammatory cytokine interleukin-8. Schizophr Res. 2010; 121(1-3):46.

209 Goines PE, Croen LA, Braunschweig D, Yoshida CK, Grether J, Hansen R, et al. Increased midgestational IFN- $\gamma$, IL-4 and IL-5 in women bearing a child with autism: a case-control study. Mol Autism. 2011 Aug 2; 2:13.

210 Musilova I, Kacerovsky M, Stepan M, Bestvina T, Pliskova L, Zednikova B, et al. Maternal serum $\mathrm{C}$-reactive protein concentration and intra-amniotic inflammation in women with preterm prelabor rupture of membranes. PLoS One. 2017;12(8):e0182731.

211 Rewatkar M, Jain S, Jain M, Mohod K. Creactive protein and white blood cell count as predictors of maternal and neonatal infections in prelabour rupture of membranes between 34 and 41 weeks of gestation. J Obstet Gynaecol. 2018 Jul;38(5):622-8.

212 Vecchié A, Bonaventura A, Carbone F, Maggi D, Ferraiolo A, Carloni B, et al. C-Reactive protein levels at the midpregnancy can predict gestational complications. Biomed Res Int. 2018 Nov 7;2018:1070151.

213 Mohaupt MG. C-reactive protein and its role in preeclampsia. Hypertension. 2015; 65(2):285

214 Jeon JH, Namgung R, Park MS, Park KI, Lee C. Positive maternal C-reactive protein predicts neonatal sepsis. Yonsei Med J. 2014; 55(1):113.

215 Hunter SK, Hoffman MC, D'alessandro A Noonan K, Wyrwa A, Freedman R, et al. Male fetus susceptibility to maternal inflammation: C-reactive protein and brain development. Psychol Med. 2021 Feb;51(3):450-9.

216 Zhang J, Luo W, Huang P, Peng L, Huang Q. Maternal C-reactive protein and cytokine levels during pregnancy and the risk of selected neuropsychiatric disorders in offspring: a systematic review and meta-analysis. J Psychiatr Res. 2018 Oct; 105:86-94.

217 Canetta S, Sourander A, Surcel HM, Hinkka-Yli-Salomäki S, Leiviskä J, Kellendonk C, et al. Elevated maternal C-reactive protein and increased risk of schizophrenia in a national birth cohort. Am J Psychiatry. 2014; 171(9):960.
218 Chudal R, Sourander A, Surcel HM, Sucksdorff D, Hinkka-Yli-Salomäki S, Brown AS. Gestational maternal C-reactive protein and risk of bipolar disorder among young individuals in a Nationwide Birth Cohort. J Affect Disord. 2017;208:41.

219 Ifdil I, Fadli RP, Gusmaliza B, Putri YE. Mortality and psychological stress in pregnant and postnatal women during COVID-19 outbreak in West Sumatra, Indonesia. J Psychosom Obstet Gynaecol. 2020 Dec;41:251-2.

220 Qiu C, Sanchez SE, Lam N, Garcia P, Williams MA. Associations of depression and depressive symptoms with preeclampsia: results from a Peruvian case-control study. BMC Womens Health. 2007;7:15.

221 Kurki T, Hiilesmaa V, Raitasalo R, Mattila $\mathrm{H}$, Ylikorkala O. Depression and anxiety in early pregnancy and risk for preeclampsia. Obstet Gynecol. 2000;95(4):487.

222 Qiu C, Williams MA, Calderon-Margalit R, Cripe SM, Sorensen TK. Preeclampsia risk in relation to maternal mood and anxiety disorders diagnosed before or during early pregnancy. Am J Hypertens. 2009;22(4):397.

223 Sandman CA, Wadhwa PD, Chicz-Demet A, Dunkel-Schetter C, Porto M. Maternal stress, HPA activity, and fetal/infant outcome. Ann N Y Acad Sci. 1997 Apr;814:266-75.

224 Di Mascio D, Khalil A, Saccone G, Rizzo G, Buca D, Liberati M, et al. Outcome of coronavirus spectrum infections (SARS, MERS, COVID-19) during pregnancy: a systematic review and meta-analysis. Am J Obstet Gynecol MFM. 2020;2(2):100107.

225 Prabhu M, Cagino K, Matthews KC, Friedlander RL, Glynn SM, Kubiak JM, et al. Pregnancy and postpartum outcomes in a universally tested population for SARS-CoV-2 in New York City: a prospective cohort study. BJOG. 2020 Nov;127(12):1548-56.

226 Mendoza M, Garcia-Ruiz I, Maiz N, Rodo C, Garcia-Manau P, Serrano B, et al. Pre-eclampsia-like syndrome induced by severe COVID-19: a prospective observational study. BJOG. 2020 Oct;127(11):1374-80.

227 Beys-da-Silva WO, da Rosa RL, Santi L, Tureta EF, Terraciano PB, Guimarães JA, et al. The risk of COVID-19 for pregnant women: evidences of molecular alterations associated with preeclampsia in SARS-CoV-2 infection. Biochim Biophys Acta Mol Basis Dis. 2021 Mar 1;1867(3):165999.

228 Joudi N, Henkel A, Lock WS, Lyell D. Preeclampsia treatment in severe acute respiratory syndrome coronavirus 2. Am J Obstet Gynecol MFM. 2020 Aug;2(3):100146.

229 Coronado-Arroyo JC, Concepción-Zavaleta MJ, Zavaleta-Gutiérrez FE, ConcepciónUrteaga LA. Is COVID-19 a risk factor for severe preeclampsia? Hospital experience in a developing country. Eur J Obstet Gynecol Reprod Biol. 2021 Jan;256:502-3.

230 Shanes ED, Mithal LB, Otero S, Azad HA, Miller ES, Goldstein JA. Placental pathology in COVID-19. Am J Clin Pathol. 2020; 154(1):23-32. 
231 Ahmed I, Eltaweel N, Antoun L, Rehal A. Severe pre-eclampsia complicated by acute fatty liver disease of pregnancy, HELLP syndrome and acute kidney injury following SARS-CoV-2 infection. BMJ Case Rep. 2020 Aug 11;13(8):e237521.

232 Hansen JN, Hine J, Strout TD. COVID-19 and preeclampsia with severe features at 34-weeks gestation. Am J Emerg Med. 2021 Jan;39:252.e3-e5.

233 Karimi-Zarchi M, Neamatzadeh H, Dastgheib SA, Abbasi H, Mirjalili SR, Behforouz $\mathrm{A}$, et al. Vertical transmission of coronavirus disease 19 (COVID-19) from infected pregnant mothers to neonates: a review. Fetal Pediatr Pathol. 2020 Jun;39(3):246-50.

234 Lu D, Sang L, Du S, Li T, Chang Y, Yang XA. Asymptomatic COVID-19 infection in late pregnancy indicated no vertical transmission. J Med Virol. 2020 Sep;92(9):1660-4.

235 Wang S, Guo L, Chen L, Liu W, Cao Y, Zhang J, et al. A case report of neonatal COVID-19 infection in China. Clin Infect Dis. 2020 Jul 28;71(15):853-7.

236 Alzamora MC, Paredes T, Caceres D, Webb CM, Valdez LM, La Rosa M. Severe COVID-19 during pregnancy and possible vertical transmission. Am J Perinatol. 2020 Jun; 37(8):861-5.

237 Aghaeepour N, Ganio EA, Mcilwain D, Tsai AS, Tingle M, Van Gassen S, et al. An immune clock of human pregnancy. Sci Immunol. 2017;2(15).

238 Alfaraj SH, Al-Tawfiq JA, Memish ZA. Middle East Respiratory Syndrome Coronavirus (MERS-CoV) infection during pregnancy: report of two cases \& review of the literature. J Microbiol Immunol Infect. 2019 Jun;52(3): 501-3.

239 Tosone G, Maraolo AE, Mascolo S, Palmiero G, Tambaro O, Orlando R. Vertical hepatitis $\mathrm{C}$ virus transmission: main questions and answers. World J Hepatol. 2014;6(8):538.

240 Davies G, Wilson RD, Désilets V, Reid GJ, Shaw D, Summers A, et al. Amniocentesis and women with hepatitis $B$, hepatitis $C$, or human immunodeficiency virus. J Obstet Gynaecol Can. 2003;25(2):145.

241 Shah PS, Diambomba Y, Acharya G, Morris SK, Bitnun A. Classification system and case definition for SARS-CoV-2 infection in pregnant women, fetuses, and neonates. Acta Obstet Gynecol Scand. 2020 May; 99(5):565-8.

242 Schwartz DA. An analysis of 38 pregnant women with COVID-19, their newborn infants, and maternal-fetal transmission of
SARS-CoV-2: maternal coronavirus infections and pregnancy outcomes. Arch Pathol Lab Med. 2020 Mar 17. Epub ahead of print.

243 Egloff C, Vauloup-Fellous C, Picone O, Mandelbrot L, Roques P. Evidence and possible mechanisms of rare maternal-fetal transmission of SARS-CoV-2. J Clin Virol. 2020 Jul;128:104447.

244 Delorme-Axford E, Sadovsky Y, Coyne CB. The placenta as a barrier to viral infections. Annu Rev Virol. 2014;1(1):133.

245 Coyne CB, Lazear HM. Zika virus: reigniting the TORCH. Nat Rev Microbiol. 2016; 14(11):707.

246 Chen S, Huang B, Luo DJ, Li X, Yang F, Zhao $\mathrm{Y}$, et al. [Pregnant women with new coronavirus infection: a clinical characteristics and placental pathological analysis of three cases]. Zhonghua bing li xue za zhi $=$ Chinese J Pathol. 2020 May 8;49(5):418-23.

247 Liu W, Wang Q, Zhang Q, Chen L. Coronavirus disease 2019 (COVID-19) during pregnancy: a case series. 2020. Preprint.

248 Yu N, Li W, Kang Q, Xiong Z, Wang S, Lin $\mathrm{X}$, et al. Clinical features and obstetric and neonatal outcomes of pregnant patients with COVID-19 in Wuhan, China: a retrospective, single-centre, descriptive study. Lancet Infect Dis. 2020;20(5):559-64.

249 Walker KF, O’Donoghue K, Grace N, Dorling J, Comeau JL, Li W, et al. Maternal transmission of SARS-COV-2 to the neonate, and possible routes for such transmission: a systematic review and critical analysis. BJOG. 2020 Oct;127(11):1324-36.

250 Zheng QL, Duan T, Jin LP. Single-cell RNA expression profiling of ACE2 and AXL in the human maternal-Fetal interface. Reprod Dev Med. 2020;4(1):7-10.

251 To KF, Tong JH, Chan PK, Au FW, Chim SS, Chan KC, et al. Tissue and cellular tropism of the coronavirus associated with severe acute respiratory syndrome: an in-situ hybridization study of fatal cases. J Pathol. 2004;202(2):157.

252 chen yongwen, Feng Z, Diao B, Wang R, Wang G, Wang C, et al. The novel severe acute respiratory syndrome coronavirus 2 (SARS-CoV-2) directly decimates human spleens and lymph nodes. 2020;2:1-18.

253 To KF, Tong JH, Chan PK, Au FW, Chim SS, Chan KC, et al. Tissue and cellular tropism of the coronavirus associated with severe acute respiratory syndrome: an in-situ hybridization study of fatal cases. J Pathol. 2004;202:157-63.
254 Tabata T, Petitt M, Puerta-Guardo H, Michlmayr D, Wang C, Fang-Hoover J, et al. Zika virus targets different primary human placental cells, suggesting two routes for vertical transmission. Cell Host Microbe. 2016; 20(2):155.

255 D’Ortenzio E, Matheron S, Yazdanpanah Y. Evidence of sexual transmission of Zika virus. N Engl J Med. 2016 Jun 2;374(22):2195-8.

256 Jain P, Thakur A, Kler N, Garg P. Manifestations in neonates born to COVID-19 positive mothers. Indian J Pediatr. 2020 Aug; 87(8):644.

257 Zeng L, Xia S, Yuan W, Yan K, Xiao F, Shao $J$, et al. Neonatal early-onset infection with SARS-CoV-2 in 33 neonates born to mothers with COVID-19 in Wuhan, China. JAMA Pediatr. 2020 Jul 1;174(7):722-5.

258 Nawsherwan, Khan S, Nabi G, Fan C, Wang S. Impact of COVID-19 pneumonia on neonatal birth outcomes. Indian J Pediatr. 2020 Aug;87(8):645-6.

259 Bhat BV, Ravikumar S. Challenges in neonatal COVID-19 infection. Indian J Pediatr. 2020;87(8):577-8.

260 Ferrazzi E, Frigerio L, Savasi V, Vergani P, Prefumo F, Barresi S, et al. Vaginal delivery in SARS-CoV-2 infected pregnant women in Northern Italy: a retrospective analysis. BJOG. 2020 Aug;127(9):1116-21.

261 Thomas P, Alexander PE, Ahmed U, Elderhorst E, El-Khechen $\mathrm{H}$, Mammen MJ, et al. Vertical transmission risk of SARS-CoV-2 infection in the third trimester: a systematic scoping review. J Matern Fetal Neonatal Med. 2020 Jul 1:1-8.

262 Jamieson DJ, Honein MA, Rasmussen SA, Williams JL, Swerdlow DL, Biggerstaff MS, et al. H1N1 2009 influenza virus infection during pregnancy in the USA. Lancet. 2009; 374(9688):451.

263 Castro P, Matos AP, Werner H, Lopes FP, Tonni G, Araujo Júnior E. Covid19 and pregnancy: an overview. Rev Bras Ginecol Obstet. $2020 \mathrm{Jul} ; 42(7): 420-6$.

264 Madinger NE, Greenspoon JS, Ellrodt AG. Pneumonia during pregnancy: has modern technology improved maternal and fetal outcome? Am J Obstet Gynecol. 1989; 161(3):657.

265 Rigby FB, Pastorek JG. Pneumonia during pregnancy. Clin Obstet Gynecol. 1996;39(1): $107-19$.

266 Liu S, Diao L, Huang C, Li Y, Zeng Y, KwakKim JYH. The role of decidual immune cells on human pregnancy. J Reprod Immunol. 2017;124:44.
Maternal-Fetal SARS-CoV-2

Transmission: Effects on the Fetus
Neuroimmunomodulation 2021;28:1-21 